\title{
GENDERED METAPHORS OF TERRITORIAL SUBORDINATION, THEOLOGIES OF INDEPENDENCE AND IMAGES OF A LIBERATED FUTURE: SODARO \& DI BELLA'S LÀSSAMI AS A SICILIAN DECOLONIAL ALLEGORY
}

\author{
METÁFORAS DE GÊNERO SOBRE SUBORDINAÇÃO TERRITORIAL, \\ TEOLOGIAS DA INDEPENDÊNCIA E IMAGENS DE UM FUTURO \\ LIBERADO: LÀSSAMI DE SODARO E DI BELLA COMO ALEGORIA \\ DECOLONIAL SICILIANA
}

Marcello Messina ${ }^{1}$

\begin{abstract}
:
The short film Làssami ("leave me") was directed by Gianluca Sodaro in 2015, and functions as a music video to the eponymous song by Giuseppe Di Bella, who also acts in the film. In this article, I attempt to decipher Làssami's encounter of lyrics, music, sound effects and images. In the first part of the article, I discuss the reproduction of stereotypical images of Sicilian masculinity perpetrated by the film, also drawing on recent media releases. I then work my way through the intricate web of trappings associated to the representation of the female characters in the film - as passive, innocent, celestial, and white. In the second part of the article, I attempt to reinterpret the film in light of the decolonial concept of "de-linking". I argue that Làssami's symbolical coding, regardless of the authors' intentions, refers precisely to a silenced desire for sovereignty and independence.
\end{abstract}

\section{KEYWORDS:}

Sicily, Independence, Imagery, Allegory, Decoloniality

\section{RESUMO:}

O curta-metragem Lássami ("deixa-me", 2015) do cineasta Gianluca Sodaro, funciona como videoclipe para a canção com o mesmo nome, de Giuseppe Di Bella, cantor que também aparece no filme como ator. Neste artigo, pretendo decifrar o diálogo entre letra, música, imagens e sonoplastia em Làssami. $\mathrm{Na}$ primeira parte do artigo, reflito sobre a reprodução de imagens estereotipadas de masculinidade siciliana perpetrada pelo filme, também fazendo referência a recentes lançamentos pela mídia. Subsequentemente, tento aventurar-me dentro da intricada rede de estereótipos femininos do filme - de mulheres passivas, inocentes, celestiais e brancas. Na segunda parte do artigo, proponho uma interpretação do filme à luz do conceito decolonial de "desencadeamento". 0 meu argumento é que a codificação simbólica de Làssami, independentemente das intenções dos autores, refere-se justamente a um desejo silenciado de soberania

1 Doutor em Composição Musical pela Universityof Leeds (2013). Atualmente Professor Colaborador e Bolsista PNPD/CAPES do Programa de Pós-Graduação em Letras - Linguagem e Identidade da Universidade Federal do Acre 
e independência.

\section{PALAVRAS-CHAVE:}

Sicília, Independência, Imaginário, Alegoria, Decolonialidade.

\section{Introduction}

The short film Làssami

1 functions as a music video to the eponymous song written and performed by Giuseppe Di Bella, who also features in the film with Angélique Cavallari. The video itself was written and directed by Gianluca Sodaro. In a nutshell, this short movie shows a man who drags a woman with a rope tied around her arms and torso. They come out of a wrecked building in the countryside, dressed as bride and groom, and he keeps dragging her across the fields until they meet a lady who is strongly reminiscent of the Virgin Mary. At that point, the man decides to release the woman and walk away. The action is counterpointed by Giuseppe Di Bella's singing in Sicilian, accompanied by guitar and double bass: "Leave me, / Don't leave me" (SODARO \& DI BELLA, 2015).

A short blurb supplements the video on its official webpage, that presents the work as "[a]n ancient, never heard Sicilian tale that is also the dreamlike, symbolic and timeless metaphor of a love story that has almost come to an end" (SODARO\& DI BELLA, 2015). I will come back to all these elements later, in an attempt to propose my interpretation of the song. Before doing that, however, I will discuss the representations of race and gender reproduced in the film.

\section{Images of Sicilian masculinity}

The work of scholars like John Dickie (1994; 1997), Gabriella Gribaudi (1997), and Joseph Pugliese (2002; 2007; 2008), among others, is fundamental in order to understand the issue of the representation of Southern Italians and Sicilians as Others within a national Italian and European context. In particular, Gribaudi focusses on the fact that the Mezzogiorno is automatically assigned the 
role of negation of the centre represented by Northern Italy (GRIBAUDI, 1997, p. 85). Importantly, Pugliese remarks on the fundamental issue that this assignation is inevitably imbricated with race (PUGLIESE, 2002; PUGLIESE, 2008). The white North constructs, from time to time, the identity of the racialised South, producing images of backwardness and amoral familism (cf. BANFIELD, 1958), savagery and criminal atavism (cf. LOMBROSO, 1900; NICEFORO, 1898), incompatibility with horizontal forms of democratic participation (cf. PUTNAM, 1993), just to name a few.

The ways in which these images intersect gender and sexuality is extremely interesting, as the 150 odd years that separate the moment of the Italian Unification from the present day are crossed by a crucial resignification of gender roles and sexual orientation, that starts taking place in the second half of the twentieth century. In this way, current representations of hyper-patriarchal, machoist, and homophobic Sicilians and Southern Italians clash with earlier tropes such as the popolo donna (womanly people), formulated by Alfredo Niceforo (1898, p. 293-295). These images often coexist rather than superseding each other, resulting in Sicily and the South of Italy being seen as both too patriarchal and too matriarchal to conform to the global protocols of (late) Eurocentric modernity. As I have illustrated elsewhere, both in solo (MESSINA, 2015a) and coauthored work (CAPOGRECO \& MESSINA, 2016), these stereotypes dramatically affect the regime of audiovisual representations.

Going back to Làssami, it is not hard to situate the scene of a man coercively dragging a woman with a rope within the ordinary imagery of Sicilian male domination. Di Bella's physical presence conforms to the corporal features normally assigned to not-quite-white Southern Italians: "dark curly hair, 'primitive' facial features, strong musculature, certain gaits and postures" 
(CAPOGRECO, 2014 p. 40). These physical features conflate with what Pugliese describes as the formulation and crystallisation of a "«melanic» Southern Italian" (PUGLIESE, 2002, p. 157) to be scrutinised and treated as a suspect. The fact that this same body is portrayed in the act of performing an extreme act of violent coercion towards a harmless (and perceivably much whiter) woman (Figure 1) recalls ever-present racist representations of Sicilian men in Italian culture. To better illustrate this concept, I need to explain that I first came across Làssami in January, 2016. A few days after this discovery, journalist Carlo Panella, commenting on an unrelated news story on Italian state TV (Rai), claimed that male Sicilians traditionally used to rape women, in the 1950s, and probably even at the present day:

Behind the facts of Cologne there is the dynamics of the gang rape: a group of drunk men, with their testosterone, free, etc. who do the things that men do, that they did in Sicily and that maybe they still do in Sicily. You know well some photos; there are some astonishing photos... The astonishing photo of 1950s Sicily, with the beddha (beautiful) girl who passes by and all the young chasers... and this thing is horrendous (PANELLA, 2016). ${ }^{2}$

In Panella's imagery, the toxic representations of Arab and African masculinity abundantly associated with the 2015/16 New Year's Eve Cologne incident ${ }^{3}$ naturally conflate with these imaginary stories of brutal Sicilian gangrapers. As argued by Gaia Giuliani, with reference to the Cologne assaults and other episodes, the conflation of external threats and internal abjects produces an "absolute Other (the monster)" in contrast with whom Europe visualises its own identity (GIULIANI, 2016, p, 98). Marta Della Libera shows that

\footnotetext{
2 "Dietro Colonia c'è la dinamica del branco: un gruppo di maschi ubriachi, il testosterone, liberi, etc. che fanno le porcate che fanno i maschi, che facevano in Sicilia e che forse fanno ancora in Sicilia, lei conosce bene certe foto, ci sono delle foto clamorose... la foto clamorosa della Sicilia negli anni '50, la beddha ragazza che passa e tutti i galletti... e questa è una cosa orrenda"

3 On the Cologne incident, see Giuliani (2016), and Della Libera (2016).
} 
what is a stake in the general political instrumentalisation of the Cologne incidents is the use of the female body as a "battleground for claims of modernity, civilisation and power over the Middle Eastern menace" (DELLA LIBERA, 2016, p. 24).

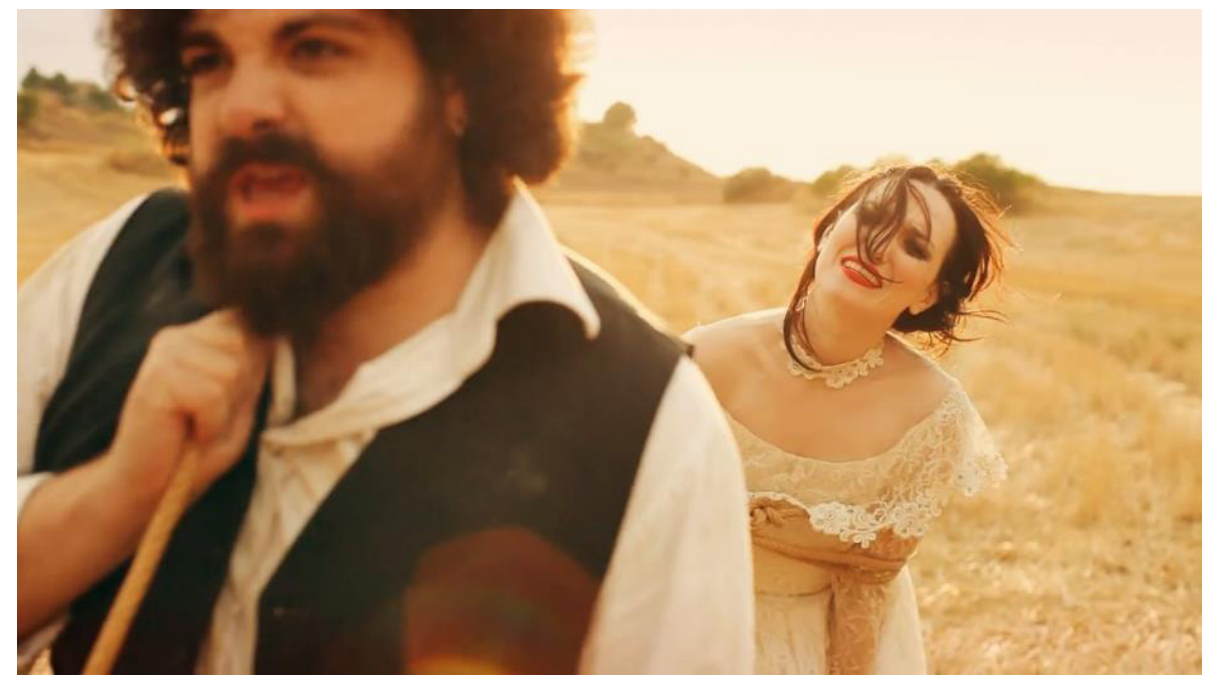

Figure 1 - The man's violent coercion of the female protagonist in Làssami. (Source: https://goo.gl/KNEHZw) ${ }^{4}$

Transposing this tension to the action portrayed in Làssami, the unmodern backwardness of the male monster resonates with the reference to the "timeless metaphor" (SODARO \& DI BELLA, 2015) made in the aforementioned introductory blurb. In general, this blurb has the function of shifting the audience both spatially and temporally, as the reference to the "Sicilian tale" is immediately complemented by a reference to timelessness: coextensive with Panella's allegations, the blurb tells us that in that place these things used to happen and might still be happening.

The characterisation of the male Sicilian as an abject individual is not just somatic, in the sense that it is not rendered solely by means of physical

4 The non-for-profit reproduction of all visual excerpts in this work complies with Brazilian Law (Lei 9.610/98, art. 46). 
and material elements. The body here is both physical and biocultural, in line with the definition of "somatechnics" provided by Pugliese and Stryker:

Somatechnics [...] suggests that embodiment cannot be reduced to the merely physical any more than it can be dematerialized as a purely discursive phenomenon. Embodiment is always biocultural, always techno-organic, always a practical achievement realized through some concrete means (PUGLIESE \& STRYKER, 2009, p. 2).

Elsewhere,

Pugliese illustrates the role of "somatechnic metonyms of an incipient criminality" (2009, p. 15), such as the beard, the hijab and the niqab, in the context of the identification of British or Australian Muslims as suspects, or as guilty "of crimes that will have always already been committed in advance of the fact" (2009, p. 15). If, as I contend in this work, Panella's conflation of Muslim/ Arabs/refugees and Sicilians is representative of a widely shared imagery, then I can plausibly argue that the long beard and the dark curly hair that compose Di Bella's stage presence could contribute to profile him as a suspect, as a ruthless kidnapper, and ultimately as a rapist (Figure 1). In Panella's above declaration, what appears evident is the implicit collocation of Sicily and Sicilians, together with Muslim/ Arabs/refugees, within a space that lies outside the Italian/ European community, that is, in the abovementioned positionality of "internal abjects", as argued by Giuliani (2016). Pugliese refers to the same process of exclusion as "prosthetic white citizenship":

Prosthetic white citizenship is what is conferred upon non-white subjects of the white nation. As a prosthetic, it is a citizenship that cannot be corporeally owned or nativised as the prosthetic of white citizenship remains visibly an adjunct to the nonwhite body. The hijab, the niqab, the Muslim cap or the black beard always give away the merely prostheticised citizen-subject. [...] Prosthetic white citizenship, as a technology of biopower, is always imposed or conferred from the outside (of the 
body); as white technè, it can only ever be taken up by its non-white subjects as simulation, precisely as a type of prosthetic or phantasmatic limb that always discloses its adjunct status as non-native artifice. Even as prosthetic white citizenship can be conferred upon non-white subjects, it can, precisely because it is viewed in terms of an artificial adjunct to the non-white subject, be withheld or taken away (PUGLIESE, 2009, p. 16).

The imminent possibility, or desirability, of taking away Italian/European citizenship from Sicilians is exactly what transpires from Panella's discourse. In this way, the moral panic that is easily triggered by evoking images of monstrous Middle Eastern men is used by Panella to pinpoint Sicilians as "the next ones": the next monsters to be stigmatised, criminalised, abjectified, and thus framed as public enemies. From this perspective, Di Bella's presence in Làssami seems to embody precisely the monstrosity that is assigned to Sicilian and Middle Eastern men.

\section{Problematic representations of female characters}

The representation of the male character in Làssami is complemented by a specular image of femininity - as passive, innocent, celestial, and white. Angélique Cavallari, who plays the female character, is an Italian/French actress born in Turin (GRASSO, 2015). She appears as endowed with a characteristic Mediterranean presence, with her dark hair and her slightly slanted eyes. In order to read the distinctive whiteness of her bridal dress, I recur again to what Pugliese terms as a "somatechnic metonym" (2009, p. 15), more precisely, the metonym of an inherent whiteness that serves as a mark of superiority to the barbaric subjectivity of the male monster. Giuliani (2015) unearths the concurrence of whiteness and Mediterraneanness in delineating an Italian racial type capable of achieving distance from the more "questionable" heritages internal to the Italian population.

In this way, within the 
settings of the "timeless metaphor" and the "ancient [...] Sicilian tale" (SODARO\& DI BELLA, 2015) portrayed in Làssami, one can easily identify, on the one hand, the Sicilian male abject, a non-white subject whose belonging to the white Italian nation is liminal and conditional, or, as Pugliese puts it, prosthetic; and, on the other hand, the white Sicilian woman, integrated in the Italian community, who embodies the recurring notion of "our women", constantly menaced by the hyper-masculine, foreign monster.

The woman is presented as being subjected, from the very beginning of the narrative of the "timeless" "Sicilian tale" of Làssami, to the violence of the man. This means that this violence, as well as the woman's subjection to it, is presented precisely as a timeless ritual, as something that, to quote Panella again, "they did in Sicily and that maybe they still do in Sicily" (PANELLA, 2016). This certainly assigns horrible features to Sicilian masculinity, as discussed above, but it also has the important effect of portraying Sicilian women as passive beings who are incapable of confronting the violence that is exerted on them.

The female protagonist of Làssami only attempts to resist once. She digs in her heels, then kneels down and tries to counter the man's attempts to pull the rope. This sequence, however, only lasts about ten seconds, after which the woman is back on her feet, following the man. This general passivity, only momentarily interrupted by a desperate attempt at resistance, coincides with the hegemonic representation of Southern women that is usually offered in Italian culture. In a previous work on audiovisual representations (MESSINA, forthcoming) I have examined how the representation of monstrous male Southern characters is at times complemented by the juxtaposition of silenced women, who passively accept the male character's behaviour, 
and only at times improvise ineffective reactions against him. In the same work, I have attempted to distinguish the diegetic violence exerted by the male characters on the female characters, from non-diegetic violence, that is, the violence that the film itself exerts on the female characters by presenting them as passive being and depriving them of their identity, their history and their ability to speak up for themselves.

Non-diegetic violence is connected with the concept of "white historicide" (PUGLIESE, 2007), formulated by Pugliese when describing the symbolically and physically violent effacing of Southern Italian cultural identities, ${ }^{5}$ instrumental to the political elimination of the South and to its conforming to a unified, North-centric Italian identity. Certainly, white historicide is extremely relevant to the representation of masculinity offered in the video, that overlooks the complexity of Sicilian masculinities and depicts them interms of the most monological and stereotypical existing form. But most importantly, white historicide is all the more relevant to Làssami when one thinks about the violent erasure perpetrated against the abundant histories of Sicilian and Southern Italian female rebellion both in internal and diasporic contexts (CALAPSO, 1980; DINO, 2016; COSCO, 2016a; COSCO, 2016b; GRIBAUDI 1997; GRIBAUDI 2010; GRIBAUDI \& MARMO 2010; PALOMBO, 2015). Importantly, female insurgence in the South is historically directed both against local patriarchal oppression and against external colonial interventions.

Once the female protagonist is deprived of her history and of her ability to rebel, she can be depicted as a pure and passive being that can only appear in the scene as a victim. This purity and passivity are imbricated with images of celestial and divine femininity, which in turn cannot be

5 In his paper, Pugliese mainly refers to the Arabic and North-African heritage that was progressively effaced from Southern Italian communities. 
dissociated from the whiteness of the female protagonist. This white, celestial, martyrised being eventually transcends into a third character, a lady that evokes the Virgin Mary, whose silent and still intervention actually dissuades the male protagonist from his violent activity. This celestial figure is dressed in white and blue and stands out for her light blue eyes and her glowing skin (Figure 2). Monique Scheer (2002) and Anna Fedele (2013) illustrate how, starting from the nineteenth century, images of the Virgin Mary started to emphasise whiteness as a necessary component of her persona, superseding all the other representations. This, importantly, affected narratives and accounts of subsequent apparitions of the Virgin, "up to Fatima in 1917 and later" (SCHEER, 2002, p. 1439):

Each appearance of Mary as a European woman reaffirmed her whiteness, adding another layer of sediment to the social construction of her appearance. After the scientific assertions that black madonnas are "actually" white, the most sympathetic interpretation left for the blackness was a patina resulting from intense devotion or simply age [...], all the while corroborating the "truth" of Mary's whiteness (SCHEER, 2002, p. 1439).

The transfiguration of Làssami's female protagonist into a glowing and celestial madonna is yet another element that confirms the link between her innocence as a victim and her whiteness. In line with Scheer's above quote, moreover, Làssami's madonna appears to be abundantly modelled after twentieth century apparitions of the Virgin, such as Fatima and Medjugorje: in particular, accounts of this last apparition are extremely close to the figure that we encounter in the videoclip, as the Medjugorje visionaries referred to "blue eyes", "rosy cheeks" and "black hair" (apud CONNEL, 2014,pp. 125, 139, 160). On the other hand, Làssami's celestial feminine figure could also be more rooted in local iconography, such as the Madonna delle Lacrime (Our Lady of Tears) in Siracusa, or Catania's Saint Agatha. Finally, 
Làssami's madonna could also be a representation of the Virgin Hodegetria, literally "she who shows the way", who is also Sicily's patron saint (CORRENTI, 1978, p. 33).

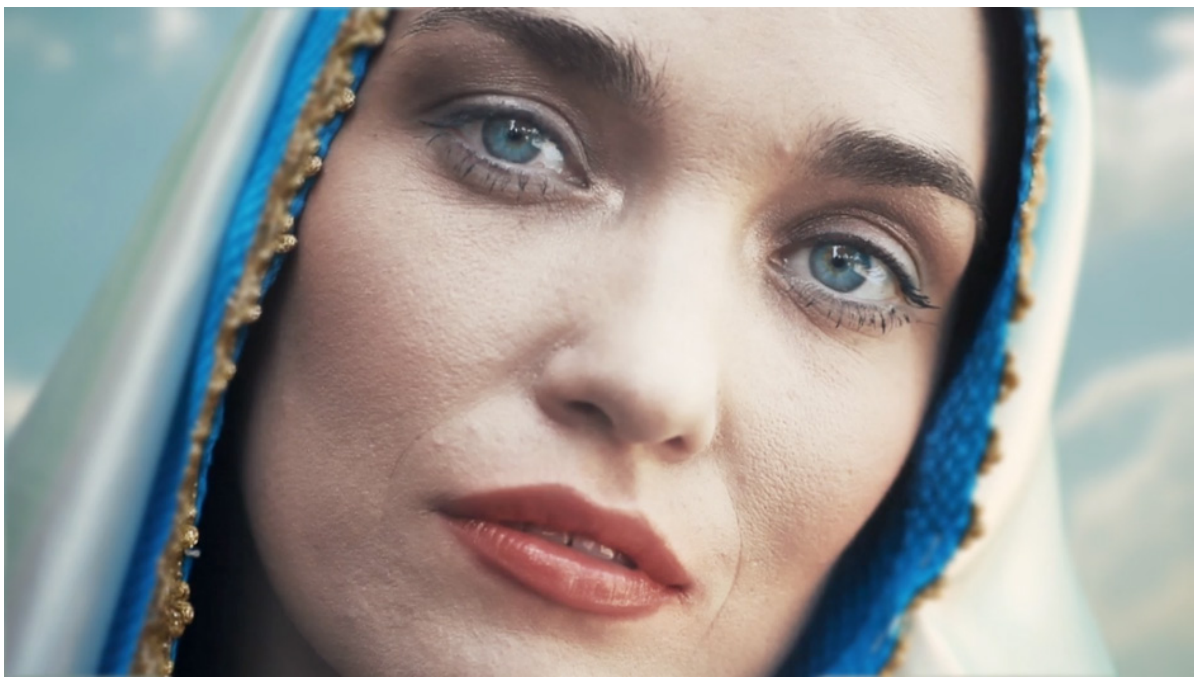

Figure 2 - Làssami's madonna. (Source: https://goo.gl/bNQQLB)

In every case, the savage thug that had been dragging the female protagonist since the beginning of the film now stops in front of the holy figure and is suddenly deterred by her holiness, or, probably, by her whiteness. He looks at the holy madonna and then looks back at the woman he has been dragging, then looks again at the madonna, decides to give up his abduction project and walks away. The madonna, interpreted by the same Angélique Cavallari, is a perfect double of the tied woman here, as she hardly does anything apart from looking at the guy and then staring down. Her celestial figure talks and acts for her, confirming the general regime of passivity assigned to women by the film.

\section{An Allegorical Reading of Làssami}

So far, I have focussed on the imagery and representations offered by Làssami in terms of gender and race relations, and their intersection with stereotypes of Sicily and Sicilians. In the second part of this article, however, I will 
focus on the allusive coding of the work, as it emerges from the encounter of sound, images and text. In this sense, I attempt to transcend the immediate issues connected to the toxic stereotypes discussed earlier, in order to look at what the work is possibly trying to say beyond its literal materiality. My allegorical reading, though, is not meant to invalidate the problems flagged above - on the contrary, their relationship with the allusive coding of Làssami will be problematised.

I need to start by declaring that when one is an Other, people will be inclined to focus on how s/he says things rather than on what s/he has to say. As Walter Mignolo would put it, what is enunciated is never detached from the place of enunciation: the apparatus of coloniality sets the premises for thought-production to be located by default in specific places that coincide with the geopolitical centres of power of the globalised world, whereas what is understood as a periphery is construed as "places of non-thought" (MIGNOLO, 2009, p. 3).

The designated places of thought-production generate knowledge that is understood as being universal and transferrable to the most disparate human situations. In an Italian national context, my thought as a Sicilian (as the thoughts of all the subjects that belong to global peripheries), can only be meaningful insofar as it communicates its own Sicilianness. Listeners are, in my personal experience, more likely to focus on my accent or on my choice of words than on the content of my delivery. Làssami, in a similar way, can only communicate to generic audiences in terms of its own Sicilianness, with all the stereotypes and images connected to this crystallised and fabricated concept. While this fact is abundantly exploited by the authors, who, as mentioned above, present their product as a "Sicilian tale", it can also come with side effects that are not necessarily under their control. 
For example, violence is normally and unquestioningly portrayed in cultural productions worldwide. When violence is part of a Hollywood movie set in the US and is enacted by white people, it is hardly signified as a characteristic regional issue: RoboCop(VERHOEVEN, 1987) or Die Hard(MCTIERNAN, 1988) are internationally acclaimed movies, and I would not think they are perceived as works that investigate the particular violence problems of Detroit and New York. On the contrary, when a book or novel is set in Sicily, and there happens to be violence in it, then that violence ceases to be universal, and becomes a specific problem connected to that particular territory. Sicilian writer Luigi Capuana lamented this exact problem with regards to the reception of his work:

A few days ago, on the Diritto, I admired these precise words about my work Le
Paesane: "There, the savagely violent scenes dominate on everything else, and this tells us that Sicily, to a great extent, is a territory that needs to be redeemed by civilisation". God Almighty! All the volume happens to be centred on the comical aspects of Sicilian life, or more specifically on the comical aspects of the life of some Sicilian carters. But then, there you go, this is how we poor souls are interpreted and judged! (CAPUANA, 1972, p. 89). ${ }^{6}$

In other words, Capuana's humorous narrative was read as stories of brutal Sicilian violence by contemporaneous commentators.

My preoccupation, consequently, is that by focussing solely on genderand race representations in Làssami, I run the risk of overlooking some important elements that might complicate these representations. In particular, the fact that Sodaro and Di Bella's aforementioned blurb deploys the signifiers "symbolic" and "metaphor" (2015), together with the

\footnotetext{
6 "Giorni fa, nel Diritto, a proposito delle mie Paesane, ho ammirato queste precise parole: 'Le scene selvaggie vi hanno il predominio sulle altre, e questo ci dice che la Sicilia, in gran parte, è terreno da redimersi alla civiltà. Benedetto Iddio! Neppure farlo a posta, appunto in tutto il volume delle Paesane è il lato comico della vita siciliana, o meglio il lato comico di certi carrettieri siciliani quello che vien messo in maggiore evidenza. Ecco come siamo letti e giudicati noi poveri diavoli!"
} 
highly imaginative setting of the mise-en-scène, are all elements that motivate me to try and unearth any allegorical coding voluntarily or involuntarily encoded in Làssami.

I understand allegory as an inherently polysemic, flexible and continuously negotiable poetic form, that has the property of putting the audience in a privileged position in terms of the construction of meaning (cf. QUILLIGAN, 1979; HUNTER, 2010; MONELLE, 2000). This means that, as a spectator of Làssami's imaginative allegory, I am tacitly encouraged to make speculations on the possible meanings that the film incorporates. This becomes all the more legitimate once it is established that allegories can be unintentional (HARIMAN, 2002, p. 283). I immediately take a cue from the lyrics of Làssami: at some point through the song, Di Bella sings, "imagination is like wax" (SODARO \& DI BELLA, 2015), as if explicitly encouraging me to mould my own interpretation of the work.
Importantly, the images in Làssami do not focus immediately on the storyline. On the contrary, the very first seconds of the film are based on the alternation between wide shots of the sunny and arid countryside where the action is about to take place, and closeups on different objects, here listed in order of appearance: a set of old cast iron keys lying on the ground in the bushes; an old dry-stone wall underneath a blue sky; the façade of an old wrecked rural house; and a dry plant covered with snails. During the main action, the camera also focusses on some limestone rocks, alongside more wrecked buildings and more walls. Finally, after the man has walked away, the camera cuts away to a barren land, where a sunray suddenly illuminates a single, bare tree (Figure 3). 


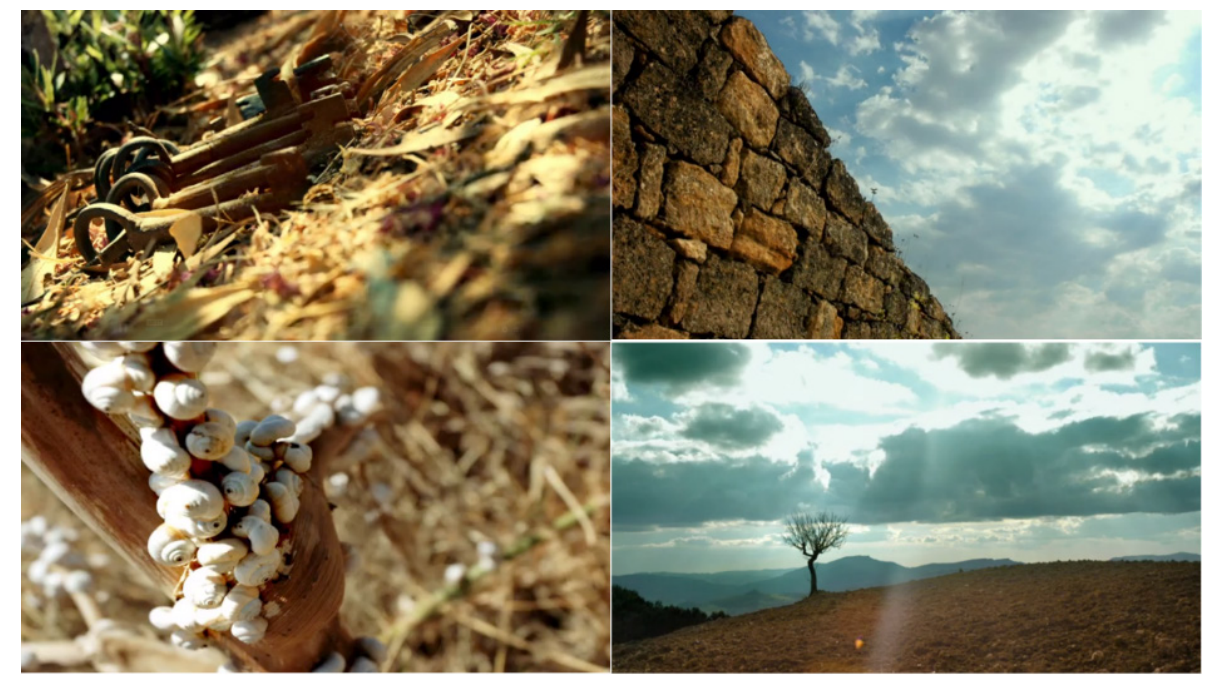

Figure 3 - Some of the objects, not immediately related with the main storyline, that appear in Làssami. (Source: https://goo.gl/bNQQLB).

All this allusive inventory obviously needs to be read together with the main symbolic event of the narrative, that is, the rope-dragging of the woman. In addition, I need to consider the way in which all these elements interact with sound, and especially with the song, in terms of both lyrics and music. Before, after and during the song, we also distinctly hear the sound of cicadas, which essentially frames the action and appears as a pre-existing element that also outlasts the action.

I see the keys as an obvious meta-clue about the referentiality of the whole work: they announce the allegory and literally function as an interpretive key. The wall, with its material status of spatial divider, may refer to the necessity of trespassing a liminal condition and accessing a different, "other" way of interpreting the work. However, in my interpretation of the work, the wall mainly evokes a geopolitical divide, a border. Significantly, this wall literally cuts the sky and prevents the spectator from fully observing it. This last image, then, can start revealing the presence of a geopolitical commentary 
encoded in Làssami. In the next sub-chapter, I will further develop this idea, with reference to the main event of the action and its interplay with other elements.

Commentary on territorial (in)dependence: the rope, the chain, and Sicily as an oppressed woman

My interpretation of the wall in terms of a border is situated in a general reading of the dichotomies North vs. South and Sicily vs. mainland as signifiers of cultural, social, ethnic, racial and political demarcations in Italy. In the words of Pugliese, "the racist North/South divide operates along this racialised geopolitical axis that demarcates the North as Aryan and European, and the South as African and Arab" (2007). In this context, narratives of the Sicilian border with the mainland are complicated, as they are not only a prerogative of Northern racist stereotypes, but also an active revindication on the part of Sicilians themselves (PARDALIS, 2009). In other words, the resort to claims for political independence is one of the most common reactions of Sicilians to racist and Northcentric narratives of Italianness.

My focus on Sicily is by no means intended to overlook the heterogeneous forms of independence politics that comes from the rest of the South. As a matter of fact, Southern resistance against a Northcentric Italy has been described in many different terms, such as "tactical blackening" (PUGLIESE, 2008), or "fuoco del Sud" ("Southern fire") (PATRUNO, 2011), or even my personal formulation of "postItalian" (MESSINA, 2015b; MESSINA, 2016a; MESSINA, 2016b; MESSINA, 2017a).

Sicilian independence politics can be partly subsumed under the wider concept of Southern resistance against Italian North-centrism, and partly regarded as an autonomous articulation, due to the particular historical developments that have characterised the relations between Sicily and the mainland since the pre- 
Unification period (MIGNEMI, 1980, TURCO, 1983). Among these historical occurrences, the most representative of a clear independence project was the post-World War II phenomenon known as Sicilian Separatism

(FINKELSTEIN, 1999; PACI\&PIETRANCOSTA, 2010). The discourses and imagery produced within and around Sicilian Separatism may prove to be extremely useful in order to decipher the allegorical coding of Lássami.

I will now focus on one more aspect of the image of the wall presented in the videoclip. The wall literally hinders the full view of the sky, almost cutting it. This sense of restrained sky is underscored by the asymmetric angulation of the shot, so that the portion of sky that we see is extremely irregular. In her acclaimed visual work $A$ Cielo Aperto, Sicilian artist Maria Rapicavoli comments on the MUOS (Mobile User Objective System), a military device of global satellite communications owned by the US Department of Defense, installed in the
Sughereta (Suvareta) natural preserve, near Niscemi, in Sicily (MESSINA, 2015c; MESSINA, 2017b). The exhibition's brief at the ISCP in Brooklyn states that " $A$ Cielo Aperto, an Italian idiomatic expression that can be translated to 'Open Sky,' contextualises Rapicavoli's current and long-term artistic research while seeking to open, and therefore disclose, Sicily's sky as a space occupied by military forces" (ISCP, 2014). According to Liz Park, A Cielo Aperto entails "video projections [...] of a single still image, a photograph of the Sicilian sky taken by Rapicavoli. Hung at odd angles, the projectors beamed down overlapping trapezoids of blue that could very easily be mistaken for the blank screen of the projector" (PARK, 2014, p. 27). Park continues to argue that Rapicavoli's visual arrangement creates a "sense of being in a hermetically sealed space of virtual control", which in turn is "amplified by the knowledge that the photographs of MUOS hung just outside of the hall" (2014, 
p. 27).I see the trapezoidal shape of the sky in Làssami as offering, pretty much as in $A$ Cielo Aperto, a commentary on Sicily's usurped airspace.

The question of usurped airspace is the source of an endless debate in Sicilian politics. As the Paris Peace Treaty established in 1947, Sicily, together with Sardinia and their minor islands, should have been permanently demilitarised (COUNCIL OF FOREIGN MINISTERS, 1946, pp. 18-19). On the contrary, the US shortly broke the agreement, and started sending troops to Sicily in January 1948 (MANCUSO, 2009, p. 45), and since then, Sicilian territory and airspace have been intensely deployed for NATO and US military missions. Various commentators have endlessly contested this issue (MIGNEMI, 1980, pp. 21-22; TURCO, 1983, pp. 190-191; COSTA, 2009, pp. 141-144).

Làssami's image of the wall that crops the open sky into a trapezoidal, enclosed space, evokes a double sense of border, as it signifies the prevention of both land and air access to a space that is itself excluded from the viewer's sight. This important visual suggestion can help me work my way through deciphering the main vision of the film, that is, the man that drags the woman tied with a rope. Like the wall/border, this image also evokes constraint and coercion and this, in light of the cartographic demarcation of "Sicilian tale" indicated by Sodaro and Di Bella in their short blurb (2015), can again be intended as a reference to the island's geopolitical condition.

The image of the rope is particularly helpful in this sense, as it can be traced back to previous images of a tied Sicily. Looking at the corpus of images and texts produced within Sicilian Separatism, I cannot refrain from identifying a close resemblance between the rope by means of which the woman is tied to the man, and the massive chain to which Sicily is tied to Italy in a very famous drawing, generally attributed to Salvatore Giuliano 
(Figure 4). In the illustration, Luca Cosmerio), Sicily appears Giuliano is portrayed in the trapped by the tentacles of a act of breaking the chain that massive octopus, whose head ties Sicily to Italy, in order to is in Rome (Figure 5). Similarly, annex the island to the US. In in a more recent illustration the cover of 1947 book Quel that has been circulating on che si pensa in Sicilia ("What the web in the past few years, we think in Sicily") by Luigi La Sicily appears to be chained to Rosa (under the pseudonym of Calabria (Figure 6).

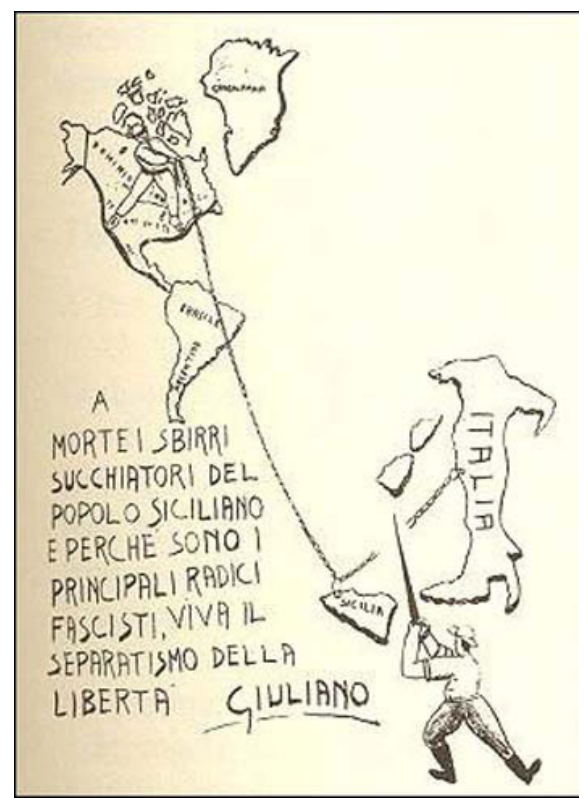

Figure 4 - An illustration attributed to Salvatore Giuliano. The writing says "Death to the cops, who suck the blood of Sicilian people, because they are the main roots of Fascism. Long life to separatism and freedom. Giuliano". (Source: public domain).

These seemingly apocry- formed by the man at the exphal and provocative images penses of the womancanbeseen certainly carry a resemblance as the allegory of a North-cenwith the main action filmed in tric nation, that practically and Làssami. In Làssami, moreover, discursively determines the the repeated dragging per- conditions of existence of Sic- 
ily and the whole South. In the song lyrics of La Sicilia havi un patruni ("Sicily has an owner"), written for singer-songwriter Rosa Balistreri, Ignazio Buttitta articulated this situation of dependency precisely in terms of a rope, held by Italy, that seizes Sicily: "Sicily has a government / An Italian government / that has a noose around her as a halter / and holds the rope in his hands" (BUTTITTA\&BALISTRERI, 1978). ${ }^{7}$ The use of masculine and feminine pronouns in my translation is not arbitrary: throughout the song, Sicily is personified as a woman and mother, who is oppressed by Italy, masculinized as a "father" (patri) and as a male "owner" (patruni). The assignation of gender roles to geopolitical entities proposed by Buttitta and Balistreri resonates perfectly within the context of gender relations in Làssami, and I will use it tostrengthen my argument about the highly allusive coding of the film.

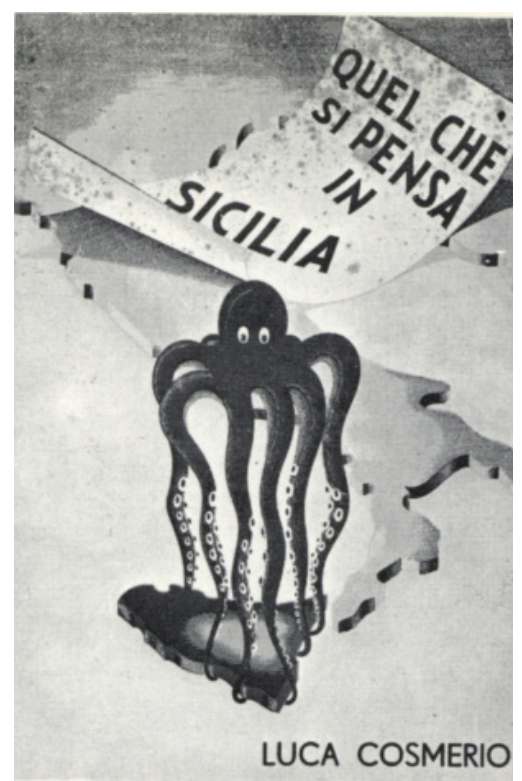

Figure 5 - The book cover of Luca Cosmerio's Quel che si pensa in Sicilia (Source: NICOLOSI, 1981).

7 La Sicilia havi un guvernu / un guvernu 'taliànu / cu la furca a lu capizzu /e la corda nna li manu. 
Before doing that, however, I will briefly focus on an aspect of the song lyrics. After the "Leave me, / Don't leave me" incipit mentioned at the beginning of this paper, Làssami's singer Giuseppe Di Bella immediately elaborates his mixed feelings: "because I loved you like I love freedom" (SODARO \&DI BELLA, 2015). Here I want to trace back the song's deployment of the signifier "freedom" to the Sicilian Risorgimento and to the unintended aspirations of freedom and independence it entailed: various cultural references could be summoned here. For example, Giovanni
Verga's Libertà, inspired in the 1860 Massacre of Bronte, begins with the peasants waving the tricoloured Italian flag and then violently rioting against the bourgeoisie in Bronte, with the motto of "viva la libertà" ("long live freedom!"). This is followed by the arrival of Nino Bixio's troops and the summary execution of five people. The other peasants involved in the riots are then convicted for various years in the waiting of a trial, and the story ends with one of them protesting "but they told there would be freedom!" (VERGA, 1885, p. 245).

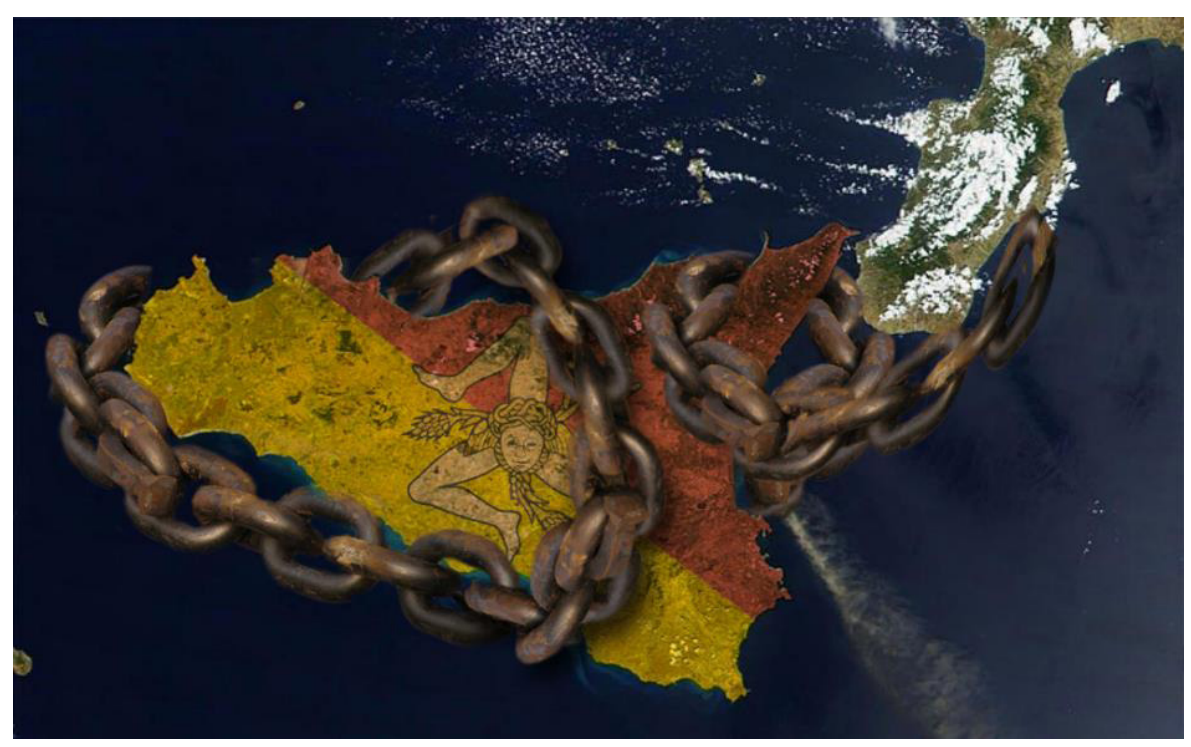

Figure 6 - A recent illustration of Sicily chained to the mainland (Source: public domain). 
The same discursive shift of the signifier "freedom" is reproduced in Antonino Uccello's anthology of Sicilian popular songs Risorgimento e società nei canti popolari siciliani (1978), where a series of songs about the enthusiasm for the freedom brought about by Garibaldi, is followed by another group of songs that reflects precisely on this freedom as a fraud that in reality came with violence and impoverishment. If among the first songs we encounter such affirmations as "it was thanks to this magic man [Garibaldi] / that Sicily got back its freedom" (ANONYMOUS apud UCCELLO, 1978, p. 177), ${ }^{8}$ then later songs begin to question this very concept of "freedom":

How nice, this freedom, by God almighty! / You know how much I worked / to get away from hell, / and now, despite all that, I ended up right in there. / It's easy to change every government, / but tyrants never change; / it's six of one, half a dozen of the other: / if one is bad, the other is even worse. // Now, this freedom, what does it give? / What are the effects of this rule? / Fights, murders, gunshots and screams, / and even the friends turn into enemies (MANGANO apud UCCELLO, 1978, p. 250). ${ }^{9}$

In 2005, Massimo Costa and Carlo Muratori wrote an unofficial Sicilian anthem titled Sicilia, Patria Mia (2005). Again, this song relies on the signifier "freedom" ("libbirtati") in order to illustrate the sudden change in Sicily's perception of Garibaldi's campaign: if initially, "with Garibaldi Sicily believed / that wealth and freedom would come about", then it is explained that the Piedmontese/ Italian Army "responded to us with bayonets", producing "emigration, mafia and poverty" (COSTA \& MURATORI, 2005). ${ }^{10}$

These cultural manifestations reveal the complex, am-

8 "Fu pri chist'omu ccu la fataciuni / ca la Sicilia fu libira arreri".

9 "Chi bella libertà, o Numi eternu! / vui lu sapiti quantu travagghiai / pi livarmi accantu di lu 'nfernu, / ora all'oppostu dda intra cascai: / è facili canciari ogni guvernu, / ma li tiranni non cancianu mai; / già suu tutti a rjini e puleju: / si unu è tintu l'autru è cchjù peju. // Ora sta libbirtà cosa produci? / Quali sunu l'effetti di sta liggi? / Scerri, umicidii, scupittati e vuci, / e l'amici divuentunu nimici".

10 "Cu Garibaldi la Sicilia critti/ d'avìrinni ricchizza e libirtati; / n'arrispunneru cu li bajunitti, / emigrazioni, mafia e puvirtati". 
bivalent and polysemic meaning of "freedom" within the Sicily-Italy relationship. Now, the aforementioned expression "I loved you like I love freedom", sung by Di Bella in Làssami, condenses this same ambivalence. Considering also the original Sicilian "i' t'amava comu la libbirtà" ("I loved you like freedom") (SODARO \&DI BELLA, 2015), this line can be interpreted as "I loved you and the freedom I (used to) associate with you" or as "I loved you so much, to the point of giving up my freedom in order to stay with you".

The ambivalence of freedom is codified into mixed love feelings right from the incipit "Leave me, / Don't leave me" (SODARO \&DI BELLA, 2015). Again, here I claim that love does not only refer to a literal and denotative reading of the action displayed in the video. Rather, the signifier "love" is part of an established manner of metaphorically describing the relationship between Sicily and Italy (and between South and North).

11 Cf. Nitti (1900) and Salvemini (1963).
In his book Separiamoci (“Let's Separate") (2013), Neapolitan economist and former member of the Napoli City Council Marco Esposito, following an intellectual path that had been partly traced by nineteenth- and twentieth-century intellectuals such as Francesco Saverio Nitti and Gaetano Salvemini, ${ }^{11}$ rigorously builds the economic case for an independent South, that meticulously covers a series of topics ranging from taxation, through to banking, education, health, insurances, and so on. Then, and precisely in the tradition of the love metaphor, Esposito closes his book with a final chapter, by the title of "Scoprirsi innamorati" ("Discovering oneself in love"):

It hardly ever happens, but it happens. Right at the moment of splitting up, you look at each other, you look at the book and the things that you bought together, and that none of you knows in which box they would go, and then you wonder whether it is really worth bidding farewell to each other. Whether, despite the quarrels and the offences, despite the unattended common pacts, it 
would not be worth giving it another chance (ESPOSITO, 2013, p, 153). ${ }^{12}$

Esposito's

apparent retraction is nothing but a rhetorical expedient, as the chapter provocatively continues by listing a series of conditions that Italy would have to comply with in order to convince the South to give up its independence aspirations (ESPOSITO, 2013, pp. 153162). Similarly, in advocating Sicilian independence by envisaging the reconfiguration of Italy into a confederation of independent states, Andrea Finocchiaro Aprile, leader of the historical Movement for Sicilian Independence, was concerned to reassure Italians as to Sicily's love for Italy: "Finocchiaro Aprile's speech is one of staunch opposition. In it, he declares that Sicilians love Italy, and that if they want to dissociate from it, in order to create a new Mediterranean confederation, no offence is to be taken" (LA SETTIMANA INCOM, 1946). ${ }^{13}$

Both the above passages are far-from-exceptional examples of the metaphor of the love relationship, that is omnipresent within the debate about Italian territorial politics, especially when the dichotomies Sicily vs. Italy and North vs. South are in operation. Rather than being solely used by Southern and Sicilian advocates of a political separation in order to reassure Italian interlocutors about the friendliness of any envisaged independence project, the love metaphor is abundantly deployed from a national Italian locus of enunciation, in order to establish the conditions of the relationship with the subaltern territory, be it the South or Sicily.

12 "Capita di rado, ma capita. Proprio al momento di separarsi si incrociano gli sguardi, si vedono i libri e gli oggetti comprati insieme e che non si saprebbe in quale scatolone mettere e ci si chiede se vale davvero la pena di dirsi addio. Se nonostante le litigate e le offese, se nonostante il tradimento dei comuni impegni, non valga ancora la pena di riprovare."

13 "Il discorso di Finocchiaro Aprile è di netta opposizione. In esso si dichiara che i siciliani amano l'Italia, e se vogliono dissociarsi da lei per creare la nuova confederazione mediterranea, ciò non deve suonare offesa." 
In particular, the during the Berlusconian era aforementioned song La Sicilia we were likely to be exposed havi un patruni (BUTTITA \& to the narrative of Berlusconi's BALISTRERI, 1974) exemplifies the fact that when Sicily is part of this love metaphor, it is often identified as a female subject to be either exploited and domesticated with the excuse of affection, or,alternatively, insulted, shamed and vilified. The image in Figure 7, a satirical illustration from a 1944 proindependence newspaper, attempts to unmask precisely this deceptive use of the love metaphor: it depicts Italy as a male lover who tries to serenade Sicily, represented in turn as a woman who looks away from the Italian wooer, and seems more interested in her own independence, embodied by a tower where a flag waves with the word "indipendenza".

The love metaphor persists as a cliché, and pretty much as we are nowadays likely to hear that even Matteo Salvini, leader of the declaredly anti-Southern party Lega Nord, "fell in love with Sicily" (ALFANO apud SICILIAINFORMAZIONI, 2014), 


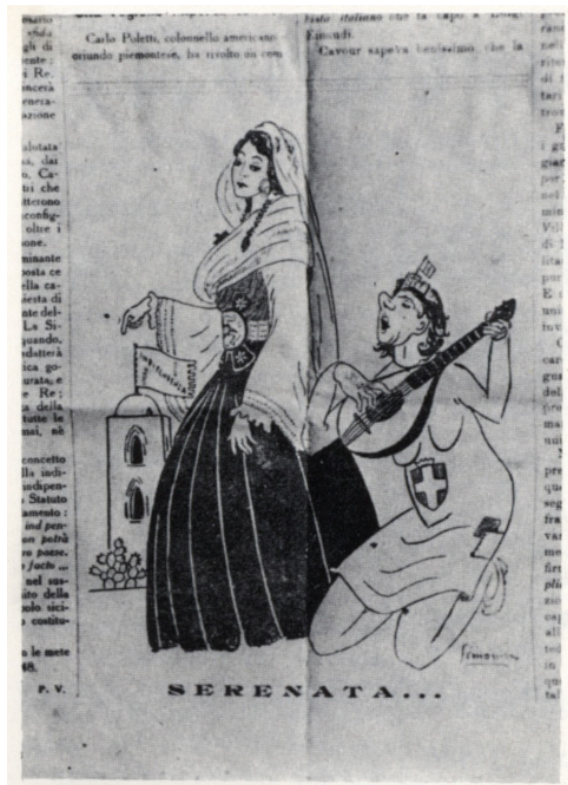

Figure 7: A 1944 pro-independence satirical illustration from the newspaper "L'indipendenza siciliana" (Source: NICOLOSI, 1981)

Franco Maresco's 2014 “between Silvio Berlusconi and mock documentary Belluscone: Sicily" (MARESCO, 2014) to una storia siciliana, for example, then unpack the usual collection is abundantly built on this racist of stereotypes on the criminal prejudice. Abundantly drawing temperament of Sicilians: on atavistic premises, the film explores the cultural practices of the low-income area of Brancaccio, in Palermo, in order to "narrate the criminal Sicilian origins of Silvio Berlusconi" (SANGUINETI apud MARESCO, 2014). At the beginning of the film, Maresco's monologic, indisputable voice-off educates the spectator on "the one-ofa-kind love story" existing "Unfortunately the gossips there's always plenty of them! allege that behind this gracious idyll there are dangerous friendships, dodgy interests and corrupt businesses. Is that true or false?" (MARESCO, 2014).

The "generous" love of Italians for Sicily is often intended as a problematic one, that could end up in the collusion 
with criminality and mafia, and hence has to be qualified by a following clarification, usually taking the form: "I love Sicily, despite all its contradictions". Here my use of the term "Italians" is not meant to be circumscribed to non-Sicilians: on the contrary, in order to be accepted as part of the Italian nation, Sicilians also need to declare the conditionality of their love for Sicily. Sicilian film director Giuseppe Tornatore, for example, typically reproduces this type of prepacked, readymade discourses, disguising them as something personal and unique: "I have got my own, really personal theory, I love Sicily, but in order to express all my love I need to be far away. When I go back to Sicily, I rediscover there all its contradictions, my anger and my impotence come back..." (TORNATORE apud FUSCO, 2000). ${ }^{14}$

Rather than being part of a purely personal theory, Tornatore's anger and frustration at Sicily's contradictions are already embedded in a crystallised and monolithic view of the island, whose identity can only be represented, in the words of Gabriella Gribaudi, on the basis of a "negation, on what it lack[s] based on an ideal model" (GRIBAUDI, 1997, p. 85), the ideal model being embodied, it comes without saying, by the North.

In an interview about the role of Sicily as an inspiration for her songs, Catanian singer-songwriter Carmen Consoli further develops the love metaphor, spicing up the gendered similitude with blatant sexist overtones, whereby Sicily is compared to a prostituta (female prostitute): [Sicily] is my home, therefore I get also a bit defensive about it. I desperately love it, even with all the rubbish. As someone said, loving Sicily is like loving a prostitute, but it means being so much in love with this prostitute, that you end up loving her and suffering, because she'll always cheat on you, won't

14 "Ho un mio, personalissimo teorema, amo la Sicilia, ma per esprimere tutto il mio amore ne devo stare lontano. Quando ci torno, ritrovo tutte le contraddizioni, ritorna la mia rabbia, l'impotenza..." 
she? She'll never be perfect as you want her to be (CONSOLI, 2015). ${ }^{15}$

Consoli's cliché of Sicily never being perfect is easily taken apart by the same theory of the South represented as negation formulated by Gribaudi (1997). What is rather striking, however, is Consoli's gratuitous and inconsiderate attack against femininity, intended to discredit Sicily, too. Furthermore, this deliberate insult, both against Sicily and against female sex workers, introduces a sort of demonstration of civic passion, a demonstration that is addressed to Italians. In fact soon after the aforementioned declaration, we see Consoli standing up and introducing a song against omertà. By reducing the struggle against the mafia to a conflict between the "silent army of people who long for change [...] and resist, stand up for their rights" and "the silent army of those who don't want to see and don't want to hear, the omertosi" (CONSOLI, 2015), Consoli gives the nod to racist stereotypes about the coextensiveness of Sicilian culture with omertà (cf. GRIBAUDI, 1989-1990, pp. 347-348), overlooking the thick web of North-driven socioeconomic, political and military forces that hinders and silences insurgence against mafia activities. However, what is truly perverse about Consoli's statement is that the description of Sicily as a prostitute appears to be functional to the civic elevation to Italianness that she later performs.

Oddly enough, the image of Sicily as a female prostitute, functional to a moral and spiritual advancement that gives access to Italianness, is not an exclusive prerogative of Carmen Consoli. One year earlier, in 2014, Pietrangelo Buttafuoco had published a pamphlet by the horrendous title of Buttanissima Sicilia ("Extremely Whorish Sicily").

15 "[La Sicilia] è la mia casa, per cui sono anche abbastanza suscettibile al riguardo. La amo terribilmente, anche con la spazzatura, o, come diceva qualcuno, amare la Sicilia è come amare una prostituta, però è essere talmente innamorati di questa prostituta che ami soffrendo, perché ti tradirà sempre, no? Non sarai mai perfetta come tu desideri che sia" 
Here the deliberate attack, both against Sicily and against women, is meant to claim back the control of Italy over the abjections of Sicilian autonomy:

Who likes politics must definitely like Sicily. Sicily is a well-known political laboratory. Except that its extremely whorish regional autonomy made it pitiful, repugnant and ultimately provincial. This is why even who likes politics does not like Sicily any more [...] [We need] the power to change laws if these laws, as dirty as the legislation that derives from the Statute of Autonomy is infected by mafia, do not permit the achievement of the one and only necessary agenda: claim back the [Italian] state in Sicily (BUTTAFUOCO, 2014). ${ }^{16}$

Again, what strikes me here is the deployment of sexist slurs in order to demonstrate and defend a political position. Far from taking a position on Buttafuoco's evaluation of Sicilian Autonomy in terms of the Statute, here I want to draw attention to how autonomy, as a general concept normally linked to self-determination, is associated to the signifier "whore". The same signifier "whore" is in turn associated with other signifiers that have to do with dirt, disgust, contamination, and this is all packed up and posed against the alleged necessity of Italy's centralised control on Sicily. What is in operation here is a fundamental dichotomy unearthed by Denise Ferreira da Silva, namely, the distinction between self-determination and necessitas (SILVA, 2014a; 2014b):

In scientific rewritings of the human body and territory, self-determination remains the exclusive attribute of the rational mind, which exists in the kingdom of freedom, where transcendentality is realised, namely where reside the ethical-juridical things of reason, modern subjects whose thoughts, actions and territories refigure universality. My mapping of raciality unearths how this political-symbolic arsenal

16 "A chi piace la politica deve piacere per forza la Sicilia. È il famoso laboratorio. Se non fosse però che la sua buttanissima autonomia regionale, l'ha resa pezzente, ripugnante $\mathrm{e}$ definitivamente provinciale. Ed è il motivo per cui la Sicilia, anche a chi piace la politica, non piace più [...] [Bisogna] avere il potere di cambiare le leggi se queste, sporche per come è infettata di mafia la legislazione derivata dallo Statuto autonomo, non permettano il raggiungimento dell'unico necessario proposito: fare tornare lo Stato in Sicilia." 
that refigures a power-effect of necessitas (formalisation) produces the 'others of Europe' in affectability, as subjects which do not play in ethical life. There, the others of Europe alone inhabit the realm of necessitas, thoroughly subjected to the constraining/regulating power which produces and determines the parts and movements of their bodies, thus responding for the inferior quality of their minds, which is signified in modes of existence flourishing in their territories (SILVA, 2014a, pp. 140-141).

In other words, in a world resignified by the "arsenal of raciality", self-determination can only be granted to European white subjects and communities, whereas necessitas (that is, other-directed control) functions (and is understood) as the only possible principle to regulate and control the lives and territories of the "others of Europe". This has extremely important implications for Sicily and Southern Italy, as it means that the frequent negation of the claims for self-determination coming from these terri- tories (as opposed to the more accepted claims of other European regions such as Catalonia, Scotland, the Basque Country, etc.) ${ }^{17}$ is indissolubly linked to the racist perception of "the inferior quality" of the minds, bodies and "modes of existence" of Sicilians/Southern Italians. Going back to Buttafuoco's Buttanissima Sicilia,the author's claim for the reinstatement of centralised state power (that is, for the reinstatement of necessitas) on Sicily is based on a gendered category of alleged deviancy that is obviously also imbricated with race. The fact that Sicily is described as a "whore", in other words, has to do with its being part of the "others of Europe", and this double deviancy provides the discursive ground for Buttafuoco's invocation of central Italian power on the island.

To sum up, what appears obvious from this corpus of discourses is that the use of the love metaphor to describe the relationship between Sicily

17 I have already raised and discussed this issue in an earlier work (MESSINA, 2016a, pp. 113-116). I take this opportunity to categorically condemn the recent episodes of inacceptable violence perpetrated by Spain against Catalan voters and leaders. 
and Italy is often associated with a personification of the two cartographic entities into gender roles, whereby Italy, almost automatically, assumes the role of the patriarch, and Sicily is represented as a woman. This personification has an ambivalent significance: on the one hand, for advocates of the island's selfdetermination, it is a strategy to signify and denounce the oppression suffered by Sicily; on the other hand, from a national Italian positionality, it serves to lay the ground for the exertion of control over Sicily, a kind of control that can be also facilitated by means of violent vilification, as in the examples involving Consoli and Buttafuoco.

The image of the rope that drags the woman in Làssami is also inherently ambivalent, as it could symbolise Sicily's recrimination for a situation of oppression, but also be read as the materialisation of the palla al piede ("ball and chain") metaphor that is usually deployed in order to describe the economic dependency of Sicily (and the South) within Italy. The racist image of the South as passive burden of a North that, in turn, carries the entire Italian economy is another trite cliché of the national Italian debate. For instance, Venetian philosopher and politician Massimo Cacciari has recently declared, in an interview for the Corriere del Mezzogiorno, that the North is Italy's "steam engine", due to the fact that in the South there is "a widespread tax evasion, not because Southerners are evil, but because there a big chunk of economy is in the hands of organised crime" (CACCIARI apudAGRIPPA, 2013).

The widely accepted idea that tax evasion is higher in the South is, in fact, a myth. In reality, the portions of GDP affected by shadow economy and criminal activities are much higher in the Centre-North of the country (ARDIZZI et al., 2011, pp. 26-30; ESPOSITO, 2013). Among other things, Cacciari's declarations were publicly confuted in a media release by 
Carmelo Petraglia (2014) and in a TV debate between Cacciari himself and Marco Esposito (2014). Tax evasion is only one of the discursive battlefields where the chimera of the North that carries the South along is constantly reproduced. Other similar myths regard ordinary and extraordinary investments (cf. LEPORE, 2012; CARLO \& CAPECELATRO, 1974, p. 49; WORLD BANK, 1995; VIESTI, 2013), and key investment areas such as health and instruction (cf. ESPOSITO, 2013; GIANNOLA, 2016; SINOPOLI \& CAMPAILLA, 2015). Importantly, the situation of Sicily is not different from the general situation of the South: the widely accepted idea that the island receives more than what it produces is actually contradicted by the available data (COSTA, 2009; ODDO, 2016).

Despite the abundance of available evidence against it, mythological representations of an economically proactive North that carries a passive South are eternally inscribed in the national imagery. Therefore, a decodification of Làssami's main action cannot ignore the participation of this national cliché in the configuration of the film's particular mise-en-scene: to a certain extent, then, the man who drags the woman is a figuration of the economically stable North that carries the indigent and recalcitrant South.

In more general terms, all the rich and contradictory imagery that codifies Sicily's racialised subordination to Italy and the frequent representation of this situation in terms of a gendered metaphor of love relationship appears to be eloquently synthesised in the central node of action in Làssami.

\section{Delinking, divine interventions and (de) colonial theologies}

Decolonial thought is based on the identification and refusal of the apparatus of coloniality, that is, a conjunction of oppression paradigms that comprehends knowledge and conscience alongside economic and military (neo)colonial control. The Latin Amer- 
ican scholars involved in the Modernity/Coloniality group identify the trappings of a global geopolitical configuration that is based on Eurocentric paradigms (QUIJANO, 2005), and that parasites the territory of knowledge. According to Enrique Dussel, coloniality is based on the "myth of modernity", which itself is based on a series of preposterous assumptions that nevertheless operate towards the conservation of a Eurocentric order (DUSSEL, 2005). Ramon Grosfoguel exposes Eurocentric "ego-politics of knowledge", that is, the idea that what is understood as scientific objectivity is only the violent imposition of Western subjectivities as universal paradigms of thought-production (GROSFOGUEL, 2008). The ramifications of coloniality do not only produce the myth of objective secular knowledge, but sets the terms of religious knowledge, via power institutions such as Christianity. In this sense, the geo-politics of coloniality is grounded on "imperial theo- and ego-politically based assumptions on the universali- ty of Western knowledge-making and institutional grounding" (MIGNOLO, 2009, p. 19). Against all this, Walter Mignolo advocates "epistemic disobedience", that is, the refusal and the subversion of categories defined by Western consciences and imposed as universal ontological and epistemological parameters in the uninterrupted process of colonial and neocolonial domination (MIGNOLO, 2009). Epistemic disobedience is necessary in order to perform what Mignolo calls "delinking", that is, the disconnection both "from the web of imperial/ modern knowledge and from the colonial matrix of power" (MIGNOLO, 2009, p. 20).

Based on these notions, is it possible to interpret the mystic climax that resolves Làssami in terms of the decolonial concept of "delinking"as a literal breaking of the colonial bond that keeps Sicily attached to Italy (and the South attached to the North). After all, the idea of a divine origin of Sicily's independence is frequently found in separatist discourses. Between 
1942 and 1944 Antonio Canepa, the then leader of the EVIS (Voluntary Army for the Independence of Sicily), disseminated a pro-independence pamphlet titled La Sicilia ai Siciliani("Sicily for Sicilians"), written under the pseudonym of Mario Turri. At that time, La Sicilia ai siciliani circulated clandestinely among separatists, a practice that partly resembles the pamphlet's contemporary samizdat recirculation among new generations of independence campaigners. ${ }^{18}$ Canepa introduces his writing by mentioning the divine origins of Sicily's insularity:

Sicily is an island. From every side, it is surrounded by the sea. God himself, in creating Sicily like that, clearly wanted to warn everyone that it had to be kept detached, separated from the mainland. This is what geography teaches us.
Unfortunately, not always this separation was preserved. People rebelled against God's will, and forcefully reunited those territories that God had well separated. However, Sicilians were not the ones who crossed the Messina Strait in order to go and rule the mainland. The people from the mainland were the ones who crossed the Strait, pretending to come and rule Sicily. We, the Sicilians, have thus repeatedly lost our freedom and our independence. We have been insulted, oppressed and, above all, exploited. We were left to misery and hunger (CANEPA, 1998). ${ }^{19}$

Here I am neither too worried about the instrumental and demagogic use of divinity, nor about the nationalistic opposition between island and mainland, also based on the false assumption that Sicily has never ever conquered anyone else beyond its

18 This text is either available in web publications curated by political movements, or included as appendix in related publications.

19 “La Sicilia è un'isola. Da ogni parte la circonda il mare. Dio stesso, nel crearla così, volle chiaramente avvertire che essa doveva rimanere staccata, separata dal continente. Ecco ciò che la geografia ci insegna. Questa separazione, purtroppo, non sempre è stata mantenuta. Gli uomini si sono ribellati al volere di Dio. E hanno voluto riunire con la forza quei territori che Dio aveva ben separato. Non sono stati, però, i siciliani a passare lo stretto di Messina per andare a comandare sul continente. Sono stati gli uomini del continente a passare lo stretto, con la pretesa di venire a comandare in Sicilia. Noi siciliani in questo modo abbiamo perduto più volte la nostra libertà, la nostra indipendenza. Siamo stati insultati, calpestati e soprattutto sfruttati. Ridotti alla miseria. Ridotti alla fame". 
aquatic borders. ${ }^{20}$ However colonial order, Canepa problematic, these discursive formulates an equal and strategies are commonly opposite decolonial theology. deployed in nationalistic This same decolonial theology narratives, including Italian seems to operate in Lássami, ones. ${ }^{21}$ Rather, what strikes me when the apparition of the is the fact that Canepa attempts to delineate a theological cosmogony of independence: to put it in Mignolo's words, Canepa attempts to revert the "theo-politics of knowledge" on which Italian national unity is based. A similar concept to that of colonial theopolitics can be found in Michael Lackey's literary comparison of Dostoevsky and Fanon, formulated as "theology of colonisation": "The primary violence of colonialism is theological, the semiotic violence of constructing the colonizer (believer) as a spiritual being and the colonized (unbeliever) as a material being" (LACKEY, 2002).

Against this theological celestial madonna convinces the man to free the woman he had been dragging along so far. Divine intervention, after all, is a recurrent trope in pro-independence cultural production. In the same $L a$ Sicilia ai siciliani, Turri/Canepa celebrates the advancement of the separatist struggle against the mainland, and observes that "Never had our mainland enemies been hit so badly like now; never had they suffered so many losses; never had they gone through so many disasters. It seems like God wants to punish them for all the evil they have done to Sicily" (CANEPA, 1998). ${ }^{22}$

The separatists had also elected the Virgin Hodegetria as their patron saint (NICOLOSI,

\footnotetext{
20 In fact, between the $12^{\text {th }}$ and the $13^{\text {th }}$ century, the Kingdom of Sicily, with capital Palermo,included mainland Southern Italy and even part of North Africa.

21 Cf. Angelo Del Boca (2005) on the myth of Italiani, brava gente.

22 "Mai come ora nostri nemici del continente hanno ricevuto tante legnate; mai hanno subìto tante perdite; mai sono andati incontro a tanti disastri. Sembra che Dio voglia punirli di tutto il male che hanno fatto alla Sicilia.."
} 
1981; CORRENTI, 1978, pp. 33-34). A 1940s prayer card, reproduced in Nicolosi (1981), contains a pro-independence invocation to the Hodegetria:

In the chaos that hangs over the world, support our people: be our guiding star. Restore our faith, give us the energies to resist, in charity and justice. Show us the way that we need to follow, and guide our Sicily to the path to which its glorious history drives her, to which God urges her (apud NICOLOSI, 1981). ${ }^{23}$

Hodegitria is the Virgin who shows the way, pretty much as Làssami's madonna literally shows the way to the man who has been so far abducting the woman, and now decides to walk away. Codified in Làssami's imaginative

mise-en-scene, there is the implicit decolonial theology on which narratives of Sicilian independence are at times predicated.

One final remark on decolonial theology has to do with the idea of martyrdom, that is perhaps implicit in the sufferings of Làssami female protagonist. The martyrdom as extreme pro-independence spasmofepistemicdisobedience is eloquently inscribed in the story of Saint Agatha, patron saint of my hometown Catania. The way in which Agatha preferred to be tortured rather than submitting herself to the rule of Roman proconsul Quintianus epitomises, more or less consciously, Sicily's historical recalcitrance to submit itself to the mainland rule. Other than transcending in a "sanctification of sexual violence", as argued by Martha Easton (1994), the repeated visualisation of the torture and of the breast mutilation involved in the Catanian cult of Agatha, inevitably codifies silenced histories of raciogendered violence committed against Sicilians. In this sense, the cult is, at least in part, a way for Catanians to revive memories of their continued colonial subordination, while also voicing their defiance of Italy's normative power.

23 "Nello scompiglio che imperversa sul mondo reggi il nostro popolo: sii nostra stella. Ravviva la fede, infondi in noi energie di resistenza, di carità e giustizia. Segnaci la via che abbiamo da seguire e guida la Sicilia nostra agli alti destini a cui la storia secolare la sospinge, a cui Dio la chiama" 
The remaining symbols(from a pro-independence perspective)

At this point in the article, it should come to no surprise for the reader that I participate in pro-independence activism and maintain contact with grassroots movements and cultural associations that campaign for the Sicily's selfdetermination. On the basis of this, and drawing upon the corpus of materials unearthed so far in this work, I will propose a reading of the remaining symbols scattered in the video.

In this context, the old wrecked rural house from which the two protagonists come out at the beginning could be read as a symbol of unified Italy as a derelict institution. The camera then lingers on a dry plant covered with snails, while we can hear the sound of cicadas. The snails and cicadas, in my interpretation of the allusive coding of the video, represent the people, silenced and secluded as the snails, but also constantly and secretly in activity, as the tirelessly singing cicadas. The perpetual contrast between received narratives on an alleged passivity of Sicilians and an often-silenced propensity for cultural and political insurgency is already embedded in the abovementioned excerpt from Carmen Consoli about the "silent army" (CONSOLI, 2015). In open polemics against the aforementioned anthropological incursions by Banfield (1958), Putnam (1993), et al, and focussing on the North-South binary, Pugliese situates this same contrast within thedichotomy civic vs. uncivic. By identifying a series of cultural practices of disobedience against the Northcentric, white monologism of the Italian nation, Pugliese defends the idea of a "grassroots civic culture that reorients the caucacentric, monoglossic nation-state space into a place that is coextensive with southern community histories, politics and cultural practices" (PUGLIESE, 2008, p. 13). Similarly, and also considering the general binary North-South rather than the Italy-Sicily one, Francesco Festa 
deconstructs the dichotomy state vs. mafias, by exposing the two as apparatuses of colonial oppression against which Southern political disobedience is constantly oriented (FESTA, 2014).

In her creative musical practice as a cuntastorii or cantastorii ("story-teller", or "story-singer"), Matilde Politi often reclaims the silenced memoires of political struggles that populate recent and old Sicilian history. In Cantata NO MUOS (aka U cuntu NO MUOS), Politi narrates, advocates and envisages the islanders' continued resistance against US military imperialism: in the song, pretty much as the cicadas are constantly singing in Làssami, Sicilian resistance is constantly burning, like "embers / under the arse of the Americans" 24 (POLITI, 2015); furthermore, to those who think that Sicilans are "lambs" 25 , Politi proudly tells that, on the contrary, "we are lions"26 (2015).
Drawing on Lara Palombo's ${ }^{27}$ inspirational analysis of Monica Pellizzari's film Fistful of Flies (PELLIZZARI, 1997), I thus interpret the sound of cicadas in Làssami as a symbol of what "can be sensed and not seen and that regulates, terrorises, resists but also creates possibilities by disrupting and transforming the disciplinary order/s" (PALOMBO, 2014, p. 93). As a matter of fact, after dissipating in the musical texture of the song, the sound of cicadas re-emerges at the end of the video, in correspondence of the image of a bare tree, which is suddenly illuminated by a sunray. I connect this last image to the symbolic language of anticolonial Sicilian association Terra e Liberazione ("Land and Liberation") that uses the "seed" and the "tree" as metaphors of the re-/in-surgence of Sicilian people against Italian colonialism. In a conference in Palermo, at the beginning of

\footnotetext{
24 "comu braci / sutta lu culu di l'amiricani"

25 "Picuruna"

26 "Nuatri semu liuna"

27 Not only I acknowledge the huge influence of Lara Palombo's work on mine: I also thank her for actively and kindly drawing my attention to this extremely important detail of Làssami.
} 
this year, Terra e Liberazione's coordinator Mario Di Mauro talked about the "Tree of Trinacria" ("Albero di Trinacria"):

The Tree of Trinacria is withered nowadays, because of a colonial spectacle that "does not take prisoners" [...] The Tree of Trinacria, with its millenarian roots and its golden branches that stretch out towards the light, is the image of sentiment. [...] Sentiment, a Sicilian conception that involves the heart and the brain, is the main weapon in our struggle for wellbeing (DI MAURO, 2017) ${ }^{28}$

Di Mauro's resort to the image of the tree as a metaphor for the slow revival of Sicilian self-determination can certainly be considered as dialoguing with the analogous utilisation of the same image by independence poet Turi Lima, in the poem L'àrvulu miu ("My Tree"): "My tree blossoms day and / night / and thus / come with me, there on the top, / You: / enjoy in the shade of / Freedom" (LIMA, 2010, p. 7). ${ }^{29}$
The similarities of Lima's and Di Mauro's imaginative language with the visual and aural symbolism that permeates Làssami provide another important clue towards my decolonial decipherment of Sodaro's and Di Bella's work: the tree reached by a sunray, in this sense, is the image of a liberated future.

I want to conclude this section by focussing on another element that appears during the central section of Làssami, namely, the limestone rocks that occupy the edge of frame in some of the shots. In community narratives, the rock and the stone often embody important notions such as territory, memory, foundation, and so on. In the particular setting of Làssami, and drawing again on Turi Lima's lyrical imagery, I see the limestone as an inanimate witness of a history that is constantly silenced, and packed "in a bag painted / with mendacities"30 (LIMA, 2010, p. 4):

28 "L’Albero di Trinakria è oggi disseccato da uno Spettacolo coloniale che «non fa prigionieri». [...] L'Albero di Trinakria, con le sue radici millenarie e i suoi rami d'oro che cercano la Luce, è l'imago del Sintimentu. [...]U Sintimentu, sicula concrezione di cuore e cervello, è l'arma di questo Combattimento per la Salute".

29 "Làrvulu miu ciurisci jornu e / notti / e perciò/ veni ccù mmia, dda supra, / Tu: / gòditi l'ùmmira di la / Libirtà".

30 "Nta lu saccu acculuratu / di minzogni" 
Here every stone is a cry, / every cry is a flower, every flower / Is a thorn, every thorn / Is a spear stuck in the heart: / every heart is flesh / pulled from this land / that beats, / this pang, / in sinthony with my soul, / that demands love, that demands justice (LIMA, 2010, p. 4). ${ }^{31}$

In brief, my interpretation of the inanimate visual elements that frame the core of the action in Làssami confirms my allegorical reading of the scenario that is presented in the video. In line with the inherent polysemic nature of allegorical coding, this is by no means the only possible reading of Làssami, nor does it claim to be its most suitable interpretation. Certainly, however, I have all the elements to defend my interpretation of Làssami as possible and plausible.

\section{Final remarks}

Defending the plausibility of a decolonial/pro-independence allegorical interpretation of the video Làssami is closely interlaced with my utilisation of a quite large corpus of materials,deployed in order to consolidate this same argument. By drawing on a vast amount of sources that address - more or less consciously/ approvingly - the issues related to political, economic and territorial sovereignty, I deliberately intended to make a statement on the fact that Sicilian independence is a recurrent topic in any kind of debate involving the island. For the assessment of the validity of my argument, I need to underscore that the presence of elements that involve a debate on independence need not be a conscious component of the construction of any trace. In this sense, I am not interested in determining whether Sodaro and/or Di Bella were actually thinking about the relations between Sicily and Italy when conceiving their collaborative multimedia work. As mentioned above, allegorical coding can well be unintentional, and still be extremely significant (cf. HARIMAN, 2002, p. 283).

Undoubtedly, part of my

31 "Ccà ogni petra è un chiantu, / ogni chiantu è un ciuri, ogni ciuri / è na spina, ogni spina / è na lancia chiantata nta lu cori: / ogni cori è carni / scippata a sta terra / ca batti, pàlpitu, / n-sintunìa ccu la me ànima, / ca voli amuri, ca voli giustizia" 
decolonial interpretation of Làssami happens to complicate the analysis of the work's gender and race stereotypes,offered in the first part of this article. Moreover, the complex interaction between the allegorical reading of the work and the critical analysis of its more literal elements could be further complicated by a deeper intermedial examination, something that has not been at the forefront in my writing of this article.

I can partly make up for this omission by observing that the rigid characterisation of gender roles in the video contrasts with the fact that the song is solely performed by Giuseppe Di Bella's male voice. While playing the role of the oppressor in the video, Di Bella also implores his partner/interlocutor to let him go in the song.From the perspective of the audience, this creates a situation of critical disorientation: who is singing this song? Who is uttering these words? Who is actually imploring whom to let them go? My response to these questions is that Di Bella manifestly identifies with the female protagonist of the video - he impersonates her in the song. This shift in the identification of the protagonists has important implications in that it undermines the harsh polarisation between the characters of the video: it has the effect of queering their gender roles by blurring the otherwise neat and violent distinction between them.

However, this extremely important detail does not destabilise the fascination with passive, innocent, celestial, and white female models that the images reveal. In particular, whiteness seems to be connected both with sanctity (in line with the tradition of white madonnas discussed above), and with liberation. Combining this association of whiteness and liberation with my allegorical reading of the video, I cannot refrain from confirming the concerns expressed by Denise Ferreira da Silva with reference to the dichotomy necessitas vs. self-determination 
and its imbrication with race (SILVA, 2014a; SILVA, 2014b). In other words, both within and outside my allegorical reading of the video, the images unmistakeably try to tell us that any (individual/collective/ territorial) liberation project needs to be mediated by a sort of "ascension" to whiteness.

In light of all this, it is extremely important to notice that my association of Làssami's madonna with forms of decolonial politics overlooks the aforementioned resemblance of this divine figure with the Medjugorje Virgin in Herzegovina. The traditions associated to the apparitions of this Virgin are in turn connected with Croatian nationalism, and more or less indirectly imbricated with "a history of violent nationalist and ethnic conflict, which was to repeat itself while the apparitional phenomenon was taking place" (SKRBIŠ, 2005). The shadow of the 1990s raciogendered violence involving in various terms also Serbs (as the side that perpetrated most ethnic cleansings and mass rapes), and Bosniaks (as the side who had by far most victims) could certainly complicate the territorial/ identitarian allegorical coding I have tried to unearth so far.

In fact, the spectacular suicide committed on 29 November 2017 - when finalising the very last review of this paper - by Slobodan Praljak upon hearing his 20-years conviction sentence at the International Criminal Tribunal for the former Yugoslavia in The Hague, has unearthed the largely unresolved resentments that govern the coexistence between Croats and Bosniaks in Bosnia (MACDOWALL, 2017). Initially collaborating in order to limit Serbian expansionism in the region, these two sides embarked in an internal war against each other between late 1992 and early 1994, before reuniting in February 1994 (GRODACH, 2002, pp. 66-69). One of the most significant events in this conflict, in which Praljak was directly involved, was the destruction of the 
Old Bridge (Stari Most) in the city of Mostar, an important symbolic site for Bosniaks, also largely understood as a connection between Bosniakdominated East Mostar and Croat-dominated West Mostar (GRODACH, 2002, p. 78).

In a nutshell, we are in presence of a racist separatist project - that of Herceg-Bosna as a Croat-only enclave within Bosnian territory - symbolically legitimised by the divine apparition of Medjugorje, whose "sacredness provided Croatians with an additional impetus to unite against the polluting Islam of Bosnian Muslims" (SKRBIŠ, 2005, p. 454). This project culminates in the destruction of a highly symbolic bridge, held as one of the emblems of the connection between Bosniaks and Croats in Mostar. All these elements fit astonishingly well within the allegorical coding of Làssami.

Praljak's condemnation as a war criminal, together with his post-mortem heroification in Croatia

(MACDOWALL, 2017), urges me to engage in an assessment of the two Sicilian military leaders of the EVIS that have been mentioned in this paper, namely, Antonio Canepa and Salvatore Giuliano, both of whom were murdered by Italian authorities. While Canepa's subversive activity was largely ascribable to a project of antifascist liberation of Sicily (FINKELSTEIN, 1999, pp. 21-22), Giuliano's trajectory is incontestably marked by the shameful massacre he perpetrated with his band in Portella della Ginestra (Gryka $e$ Spartave or else Purtelja $e$ Gjineshtrës in Albanian; Purtedda in Sicilian), on 1 May 1947, when the trajectory of the EVIS had already ended (FINKELSTEIN, 1999, p. 182). The massacre resulted in the killing of local rural workers, mainly from the Arbëreshë community (an Albanian-speaking Southern Italian minority), who were celebrating the International Worker's Day and cheering the recent electoral victory of the Communist/Socialist People's Block. The racial overtones of the massacre, together with 
its impelling anti-communist drive, make it very difficult to avoid comparing Giuliano to Praljak as a ruthless perpetrator of racialised political violence, regardless of the largely obscure and secreted circumstances in which the Portella massacre was commissioned by important pieces of the Italian state in association with the mafia. In this sense, I want to clarify that there exists a fundamental boundary between decolonial aspirations of independence and xenophobic nationalistic agendas: the protection of this fragile distinction needs to be at the forefront of any political project concerned with forms of political liberation.

The unanimated objects thatcompose the rich allegorical iconography of Làssami are, indeed, also readable as visual references to the memory of the Portella massacre. The stunning mountainous landscape of Portella hosts nowadays a memorial of the tragedy, that is composed precisely by two of the key elements discussed above with reference to the Làssami video clip: namely, a set of monumental limestones and dry-stone walls:

A dry-stone wall runs along a typical trazzera, ${ }^{32}$ and they both cut the earth like a wound 40 metres lengthwise, in the same direction of the bullets. Some big rocks stand all around, covering an area of a square kilometre, where the comrades of 1 May 1947 died (MICACCHI, 1982, p. 9) ) $^{33}$

A land art composition by Ettore de Conciliis in collaboration with Rocco Falciano and Giorgio Stockel, the memorial contains various inscriptions, engraved in the rocks, that engage with the memory of the massacre (MICACCHI, 1982, p. 9). Among them, a lyrical fragment by Ignazio Buttitta, resonates with my above discussion on the role of stones in Làssami: "My heart / after so many years, / is in Purtedda, / in the stones / and in the blood / of the killed / comrades"34

32 Sicilian rural footpath. Not surprisingly, a trazzera appears in Làssami, too.

33 "Un muro a secco fiancheggiato da una tipica «trazzera» per una lunghezza di circa 40 metri tagliano, nella direzione degli spari, laterra come una ferita. Tutt'intorno, per un'area di un chilometro quadrato, dove caddero i compagni del $1^{\circ}$ Maggio 1947, si innalzano dei grandi massi"

34 Poem by Ignazio Buttitta, inscribed on a memorial stone in Portella della Ginestra: "U 
The fact that Salvatore Giuliano and Ignazio Buttitta, two of the producers of Sicilian decolonial discourses presented in this article, occupy the most antipodal positions in the context of the Portella massacre is extremely emblematic of the complex, contradictory and heterogeneous nature of Sicilian independence narratives. To complicate things further, it is necessary to notice that Buttitta wrote a popular cantastorii song about Giuliano, La vera storia di Salvatore Giuliano, where he both celebrates and criticises the bandit (BUTTITTA, 1997). Originally sung by Cicciu Busacca, this song has become part of the repertoire of many cantastorii, including Matilde Politi.

This thick web of contradictions and complications, alongside the undeniable shadows that hang over the historical trajectory of 1940s Sicilian Separatism, do not absolve Italy from its disgraceful legacy as an occupying colonial force in Sicily during the Fascist ventennio and in the post-armistice and post-War World II period. Among the various infamous episodes of this history of violence, it is important to highlight the 1944 massacre in via Maqueda, Palermo, when the Italian army opened fire on the unarmed population killing 39, and the repeated retaliations against the population of Montelepre,literally as a punishment for those who were living in Salvatore Giuliano's hometown. ${ }^{35}$

Despiteall these unresolved problems, I want to claim that the rich imagery contained in Làssami articulates extremely important points that have to do with the codification of Sicilian decolonial politics. By means of its allegorical coding and its intertextual dialogue with the vast corpus of materials that I have revealed in this article, Làssami tells us that not only is a debate on Sicilian sovereignty

me cori / doppu tant'anni / è a Purtedda / Enta petri / enta sangu / di cumpagni / ammazzati".

35 Joseph Pugliese mentions these violent episodes against the population of Montelepre in his contribution to this same dossier. 
possible and desirable - it is also already embedded even in the most disparate forms of cultural production.

\section{Bibliography}

AGRIPPA, A. Cacciari: «L'evasione resta solo al Sud, ecco come si frena il treno del Nord». Corriere del Mezzogiorno. 28 December 2013. https://goo.gl/pGKtb3 ARDIZZI, G.;PETRAGLIA, C.; PIACENZA, M.; TURATI, G. L'economia sommersa fra evasione e crimine: una rivisitazione del Currency Demand Approach con una applicazione al contesto italiano.Atti della XXIII Conferenza SIEP, 2011. https:// goo.gl/GJgqVm

BANFIELD, E. C. The Moral Basis of a Backward Society.Glencoe, IL: Free Press, 1958.

BUTTAFUOCO, P. Buttanissima Sicilia: Dall'autonomia a Crocetta, tutta una rovina. Milão: Bompiani, 2014

BUTTITTA, La vera storia di Salvatore Giuliano. Palermo: Sellerio, 1997

BUTTITTA, I.; BALISTRERI, R. La Sicilia havi un patruni.Vinni a cantari all'ariu scuvertu.Cetra, 1978.

CALAPSO, J. Donne Ribelli: un secolo di lotte femminili in Sicilia, Palermo: Flaccovio, 1980. CANEPA, A. La Sicilia ai siciliani. In La sicilianità nella politica attuale, Bagheria: Federazione “Noi Siciliani", 1998, pp. 5-14.
CAPOGRECO, S. Italianness, Interrupted: (De)centring "self" at the transgressive boundaries and internal fissures of nation. BA Thesis, University of Melbourne, 2014.

CAPOGRECO, S.; MESSINA, M. The Queer Masculinity of the Global Peripheries:"Homem não chora" and "Maruzzella". Anais do $X$ Simpósio Linguagens e Identidades da/na Amazônia Sul-Ocidental, 2016.

CAPUANA, L. Verga e D'Annunzio. Bologna : Cappelli, 1972.

CARLO, A.; CAPECELATRO, E. M. Against the "Southern Question". International Journal of Sociology, v. 4, n. 2/3, 1974, pp. 31-84.

CONNELL, J.T., The Visions of the Children: The Apparitions of the Blessed Mother at Medjugorje. New York: St. Martin's Griffin, 2014.

CONSOLI, C. Coi social network ascolti i pensieri della gente. È insano. La Repubblica, 19 January 2015. https://goo.gl/K8dGqN CORRENTI, S. Saggi siciliani di storia e di letteratura. Catania: Edizioni Greco, 1978.

COSMERIO, L. (Luigi LA ROSA). Quel che si pensa in Sicilia. Catania: Movimento Indipendentista Siciliano, 1947. COSCO, S. Femminil mostro in brigantesca spoglia: Le donne briganti dell.Italia postunitaria tra realtà e mistificazione. Roma: Aracne, 2016a. 
CosCo, S. A literatura sobre o "Brigantaggio" feminino: o caso único de Maria Rosa Cutrufelli. In: RICCI, Debora; RITA, Annabela; VILELA, Ana Luísa; SEVERINO, Isa; SILVA, Fabio Maria da (orgs.) Feminino plural: literatura, língua e linguagem nos contextos italiano e lusófono, Lisboa: CLEPUL, 2016b, pp. 367376.

COSTA, M. Lo statuto speciale della Regione Siciliana: Un'autonomia tradita?Palermo: Herbita, 2009.

COSTA, M.; MURATORI, C. Sicilia Patria Mia. Palermo: L'Altra Sicilia, 2005.

COUNCIL OF FOREIGN MINISTERS. Peace Treaty with Italy. Draft Peace Treaties with Italy, Rumania, Bulgaria, Hungary, and Finland.Paris: International Paris Peace Conference, 1946. https://goo.gl/QHLASa

DEL BOCA, A. Italiani, brava gente?. Vicenza: Neri Pozza Editore; 2005..

DELLA LIBERA, M. Sex with the Other: Anxieties and Representations of Gender in Europe during theRefugee Crisis.International Journal of Multicultural and Multireligious Understanding, v. 3, n. 6 2016, pp. 19-29.

DICKIE, J. The South as Other: From Liberal Italy to the Lega Nord. The Italianist, v. 14, n. Special Issue Culture and society in southern Italy: past and present, 1994, pp.
124-140.

DICKIE, J. Stereotypes of the Italian South, 1860-1900. In: LUMLEY, R.; MORRIS, J. The New History of the Italian South: The Mezzogiorno Rivisited. Exeter: University of Exeter Press, 1997. pp. 114-147.

DI MAURO, M. L'Albero di Trinakria nel Secolo XXI. Katabba del $10^{\circ}$ Cuncùmiu della Comunità Siciliana "TerraeLiberAzione". Terra e Liberazione, v. 31, 2017.

DINO, A. Antimafia e movimenti delle donne. Protagoniste, culture e linguaggi. Rivista di Studi e Ricerche sulla criminalità organizzata, vol. 2, n. 3, 2016, pp. 3-23.

DUSSEL, E. Europa, modernidade e eurocentrismo. In LANDER, E. (org.) A colonialidade do saber: eurocentrismo e ciências sociais. Perspectivas latino-americanas. Buenos Aires: CLACSO, 2005 pp. 55-70.

ESPOSITO, M. Separiamoci. Milano: Magenes,2013.

FINKELSTEIN, M. S. Separatism, the Allies, and the Mafia: The Struggle for Sicilian Independence, 1943-1948. Cranbury: Lehigh University Press,1999.

PACI, D.; PIETRANCOSTA, F. Il separatismo siciliano (19431947). Diacronie. Studi di Storia Contemporanea, vol. 3, 2010. FEDELE, A. "Black" madonna versus "white" madonna: Gendered power strategies in alternative pilgrimages to Marian 
shrines. In FEDELE, A.; KNIBBE, $K$. (orgs.)Gender and Power in Contemporary Spirituality: Ethnographic Approaches. New York: Routledge, 2013, pp. 96-114 FESTA, F. Oltre l'emergenza: Pratiche ed esperienze di "comune" nel Sud d'Italia. In: ORIZZONTI MERIDIANI (org.)Briganti o emigranti: Sud e movimenti tra conricerca e studi subalterni. Verona: Ombre corte, 2014, pp. 191-208.

FUSCO, M. P. Nuovo cinema Tornatore. Lo sguardo sulla Sicilia.

La Repubblica. 9 June 2000. https://goo.gl/NiiZ1j

GIANNOLA, A. Nord e Sud. Università pubblica e asimmetrie italiane. Itinerari di ricerca storica, v. 30 , n. 1, 2016, pp. 134148.

GIULIANI, G. Monstrosity, Abjection and Europe in the War on Terror. Capitalism Nature Socialism, v. 27, n.4, 2016, pp. 96114.

GIULIANI, G. Mediterraneità e bianchezza. Il razzismo italiano tra fascismo e articolazioni contemporanee (1861-2015). Iperstoria, n. 6, 2015, pp. 167182.

GRASSO, I. Tra l'Italia e la Francia: Angélique Cavallari, artista a tutto tondo. La Gazzetta delloSpettacolo, 22 November 2015. https://goo. gl/AXwKNB

GRIBAUDI, G. Nord e Sud: Una geografia simbolica. Contemporanea, vol. 13, n. 1,
2010, pp. 105-118

GRIBAUDI, G. Images of the South: The Mezzogiorno as seen by Insiders and Outsiders. In LUMLEY, R.; MORRIS, J., (orgs.)The New History of the Italian South: The Mezzogiorno Revisited, Exeter: University of Exeter Press, 1997, pp. 83-113.

GRIBAUDI, G.; MARMO, M. Che differenza fa. Meridiana, n. 67, 2010, pp. 9-20.

GRIBAUDI, G. Mafia, culture e gruppi sociali. Meridiana, n. 7-8, 1989-1990, pp. 347-358.

GRODACH, C. Reconstituting identity and history in post-war Mostar, Bosnia-Herzegovina. City, vol. 6, n. 1, 2002, pp. 61-82.

GROSFOGUEL, R. Para descolonizar os estudos de economia política e os estudos pós-coloniais: transmodernidade, pensamento de fronteira e colonialidade global. Revista Crítica de Ciências Sociais, n. 80, p. 115-147. 2008 HARIMAN, R. Allegory and Democratic Public Culture in the Postmodern Era. Philosophy and Rhetoric, v. 35, n. 4, 2012, pp. 267296.

HUNTER, L. Allegory Happens: Allegory and the Arts Post1960. In COPELAND, R.; STRUCK, P. T. (orgs.), The Cambridge Companion to Allegory (pp. 266-280). Cambridge: Cambridge University Press, 2010, p. 266-280. ISCP. Maria Rapicavoli: A Cielo Aperto, 2014. https://goo.gl/ gU74LS 
LACKEY, M. Frantz Fanon on the Theology of Colonization. Journal of Colonialism and Colonial History, vol. 3, n. 2, 2002.

LA SETTIMANA INCOM,Cronache siciliane: Finocchiaro Aprile. Campagna elettorale per l'elezione alla Costituente di rappresentanti del Movimento Indipendentista

Siciliano.

Roma:Istituto Luce Cinecittà,1946. https://goo.gl/qc1BkB

LAURIA, E. Berlusconi e il "granaio" Sicilia storia d'amore e di promesse tradite. La Repubblica, 13 November 2011. https://goo. gl/RW7NjE

LEPORE, A. L'andamento della spesa per l'intervento straordinario nel Mezzogiorno d'Italia, dalla golden age alla fine del XX secolo. Revista Española de Historia de la Contabilidad, $n$. 16, 2012, pp. 76-119.

LIMA, T. L'arvulu miu. Terra e Liberazione, v. 15, 2000, p. 7.

LIMA, T. Cca ogni petra è. Terra e Liberazione, v. 15, 2000, p. 4.

LOMBROSO, C. L'ultimo brigante: Giuseppe Musolino. Nuova Antologia, 181, 1900, pp. 508-516 MACDOWALL, A. Slobodan Praljak's suicide reopens old wounds in Bosnia, The Guardian, 2 de dezembro de 2017

MANCUSO, D. Pio La Torre: Una vita per la Sicilia. Thesis: Università di Palermo. 2009.

MICACCHI, A Portella anche le pietre ora ricordano quel giorno di maggio. L'Unità,18 de maio de
1982, p. 9.

MARESCO, F. Belluscone: Una storia siciliana.Palermo: Ila Palma, 2014.

MCTIERNAN, J. Die Hard. US: Silver Pictures,1988.

MESSINA, M. The Demonization of the South and the Southernification of Evil in Contemporary Italian Cinema: Belluscone and Qualunquemente. Journal of Italian Cinema and Media Studies, [forthcoming]. MESSINA, M. Definire il postitaliano Tentativi di superamento dell'orizzonte nazionale italiano nel Mezzogiorno, eleaml.org, 20 January 2017a. https://goo.gl/ G4TCQ6

MESSINA, M.Performance-asResistance and Resistance-asPerformance in the NO MUOS Movement in Sicily. Muiraquitã, v. 5, n. 1, 2017b, pp. 50-94.

MESSINA, M. Narrativas pósitalianas A re-imaginação da unidadenacional nas canções do sul da Itália.Muiraquitã, v. 4, n. 1, 2016a, pp. 113-125

MESSINA, M. Liberation, Redemption, Autonomy: Contemporary Utopias in Southern Italian Popular Music. In: Olkusz, K.; Kłosiński, M.; Maj, K. M. More After More: Essays Commemorating the Five-Hundredth Anniversary of Thomas More's Utopia. Krakow: Facta Ficta Research Centre, 2016b, pp. 376-392.

MESSINA, M. Matteo Garrone's Gomorra: A Politically Incorrect 
Use of Neapolitan Identities and Queer Masculinities? gender/ sexuality/italy, n. 2, 2015a, pp. 179-187.

MESSINA, M. "Nuatri semu un populupisempri!":(De)Coloniality, Autonomism and "Post-Italianism" in Sicilian Songs. Proceedings of the AATI Conference in Siena [Italy], June 17-21, 2015. Section Cultural Studies. AATI Online Working Papers, 2015b.

MESSINA, M. NO MUOS: Practices of Resistance in Sicily against the US Military Communications Satellite System. In ALBUQUERQUE, G. R.; ISHII, R. A.; NASCIMENTO, F. L. (orgs.), Anais do IX Simpósio Linguagens e Identidades da/ na Amazônia Sul-Ocidental: Línguas eLiteraturas Indígenas. Rio Branco: Nepan Editora, 2015c, pp. 859-871. https://goo.gl/ ojmpdB

MIGNEMI, G. La questione siciliana: Alla luce delle violazioni al Trattato di Pace con l'Italia, alla Costituzione Italiana, allo Statuto della Regione Siciliana.Catania: Unione Siciliana., 1980

MIGNOLO, W. Epistemic Disobedience, Independent Thought and Decolonial Freedom. Theory, Culture \& Society, vol. 26, n. 7-8. 2009, pp.159-181.

MONELLE, R. The Sense of Music: Semiotic Essays. Princeton; Oxford: Princeton University Press, 2000

NICEFORO, A. L' Italia barbara contemporanea: Studi e appunti.
Milão; Palermo: R. Sandron. 1898. NICOLOSI, S. Sicilia contro Italia: il separatismo siciliano. Catania: Tringale, 1981.

NITTI, F. S. Nord e Sud: Prime linee di una inchiesta sulla ripartizione territoriale delle entrate e delle spese dello Stato in Italia. Torino: Roux e Viarengo, 1900.

ODDO, G. Un bilancio lacrime e sangue. L'Espresso, 26 de maio de 2016, pp. 29-30.

PALOMBO, L. The Racial Camp and the Production of the Political Citizen: A genealogy of contestation from Indigenous populations and Diasporic Women. PhD Thesis. Sydney: Macquarie University, 2015.

PALOMBO, L. The Fistful of Flies: A Feminist Hyphenated Disruption and Transformation of Biopolitical Interpellation, Journal of Intercultural Studies, v. 35, n. 1, 2014, pp. 91-106.

PARK, L. Maria Rapicavoli: A Cielo Aperto. Afterimage, vol. 42, n. 2, 201, pp. 26-27.

PARDALIS, S. Terroni and Polentoni: Where Does the Truth Lie? An Anthropology of Social Networks And Ethnicity inPalermo (Sicily), Italy. PhD Thesis.Duhram University, 2009.

PATRUNO, L. Fuoco del Sud: La ribollente galassia dei Movimenti meridionali. Soveria Mannelli: Rubbettino, 2011.

PANELLA, C. Unomattina, Carlo Panella: «Gli immigrati a Colonia 
hanno fatto le porcate che i maschi fanno in Sicilia», Corriere TV, 17 January 2016. https://goo.gl/ N9u1LJ

PARK, L. Maria Rapicavoli: A Cielo Aperto. Afterimage, vol. 42, n. 2, 201, pp. 26-27.

PELLIZZARI, M. Fistful of Flies. Australia: Long Black Productions, 1997.

PETRAGLIA, C. Il Sud ferma il treno del Nord. Massimo Cacciari e altri luoghi comuni. Economia e Politica, 17 January 2014. https:// goo.gl/PpgcGu

POLITI, M. U cuntu "No MUOS". Performed by Matilde Politi. No MUOS Day, Niscemi. 30 de março de 2013. https://goo.gl/dCsrg9 PUGLIESE, J. Race as category crisis: Whiteness and the topical assignation of race. Social Semiotics, v. 12, n. 2, 2002, pp. 149-168.

PUGLIESE, J. Whiteness and the blackening of Italy: La guerra cafona, extracommunitari and provisional street justice. PORTAL Journal of Multidisciplinary International Studies, v. 5, n. 2, 2008.

PUGLIESE, J. White Historicide and the Returns of the Souths of the South. Australian Humanities Review, n. 42, 2007.https://goo. $\mathrm{gl} / \mathrm{Raf} 7 \mathrm{nP}$

PUGLIESE, J. Compulsory visibility and the infralegality of racial phantasmata. Social Semiotics, v. 19, n.1, 2009, pp. 9-30.

PUGLIESE, J.; STRYKER, S.
The somatechnics of race and whiteness. Social Semiotics, v. 19, n. 1, 2009, pp. 1-8.

PUTNAM, R. D. Making Democracy Work: Civic Traditions in Modern Italy. Princeton: Princeton University Press, 1993.

QUIJANO, A. Colonialidade do poder.In LANDER, E. (org.) A colonialidade do saber: eurocentrismo e ciências sociais. Perspectivas latino-americanas. Buenos Aires: CLACSO, 2005, pp. 117-142.

QUILLIGAN, M. The Language of Allegory: Defining the Genre. Ithaca; London: Cornell University Press, 1979.

SALVEMINI, G. Movimento socialista e questione meridionale.Milão: Feltrinelli. 1963.

SCHEER, M. From Majesty to Mystery: Change in the Meanings of Black Madonnas from the Sixteenthto Nineteenth Centuries 2002, p. 1439

SICILIAINFORMAZIONI, Salvini innamorato della Sicilia Alfano: "Gli pago un caffè". Sicilia Informazioni, 16 June 2014. https://goo.gl/t2bcyA

SINOPOLI \& CAMPAILLA, L'agonia delle università del Sud. Il Manifesto, 20 August 2015. https://goo.gl/YirrND SILVA, D. F. Ninguém: direito, racialidade e violência, Meritum, v. 9, n.1, 2014a, pp. 67-117.

SILVA, D. F. No-bodies: law, raciality 
and violence, Meritum, v. 9, n.1, 2014b, pp. 119-162.

SKRBIŠ, Z. The apparitions of the Virgin Mary of Medjugorje: the convergenceof Croatian nationalism andher apparitions, 2005

SODARO, G.; DI BELLA, G.Làssami. Mizzica Boys, 2015. https://goo. gl/bNQQLB

TURCO, N. L'essenza della Questione Siciliana: Storia e Diritto 1812-1983. Catania: Centro Studi Storico-Sociali Siciliani,1983. UCCELLO, A. Risorgimento e società nei canti popolari siciliani. Catania: Pellicanolibri, 1978. VERGA, G. Libertà. In Novelle
Rusticane. Torino: F. Casanova, 1885.

VERHOEVEN, P. RoboCop. US: Orion Pictures, 1987.

VIESTI, G. "Il Sud vive sulle spalle dell'Italia che produce” (Falso!). Bari: Laterza, 2013.

WORLD BANK, Cassa per il Mezzogionno and the Economic Development of Southern Italy. International Bank for Reconstruction and Development. DepartmentofOperations-Europe, Africa and Australasia.1995.

Data de recebimento: 05/12/2017 Data de aceite: 30/12/2017 